\title{
Corporate Governance in the Asian Financial Crisis
}

\author{
By: Simon Johnson, Peter Boone, Alasdair Breach and Eric Friedman
}

Working Paper Number 297

November 1999 
Revised: November 15, 1999

Please send any comments to sjohnson@ mit.edu

Corporate Governance in the Asian Financial Crisis

\author{
Simon Johnson \\ MIT \\ Peter Boone \\ Brunswick Warburg \\ Alasdair Breach \\ Goldman Sachs \\ Eric Friedman \\ Rutgers
}

\begin{abstract}
The "Asian Crisis" of 1997-98 affected all the "emerging markets" open to capital flows. Measures of corporate governance, particularly the effectiveness of protection for minority shareholders, explain the extent of depreciation and stock market decline better than do standard macroeconomic measures. A possible explanation is that in countries with weak corporate governance, worse economic prospects result in more expropriation by managers and thus a larger fall in asset prices.
\end{abstract}

\footnotetext{
* Helpful comments on earlier drafts were provided by Olivier Blanchard, Ricardo Caballero, Stijn Claessens, Douglas Diamond, Stephanie Flanders, Mary Kwak, Rafael La Porta, Don Lessard, Richard Locke, Florencio Lopez-de-Silanes, Stewart Myers, Andrei Shleifer, Ed Steinfeld, Scott Stern, Ksenia Yudaeva, Luigi Zingales, three anonymous referees, and seminar participants at the NBER corporate finance workshop, the Stockholm School of Economics, and the Federal Reserve Bank of Chicago. Florencio Lopez-de-Silanes kindly provided access to unpublished data. Konstantina Drakouli and Matthew Utterback were very helpful research assistants. Generous support was provided by the MIT Entrepreneurship Center and the Russian-European Centre for Economic Policy (RECEP).
} 


\section{Introduction}

What caused the large exchange rate depreciations and stock market declines in some Asian countries during 1997-98? The three main explanations for the "Asian Crisis" emphasize macroeconomic and banking issues. The standard Washington view attributes the Asian Crisis to inappropriate macroeconomic policy during the 1990s, made worse by inept management of the initial depreciation in 1997 (Greenspan 1998, Corsetti, Pesenti, and Roubini 1998). In contrast, Radelet and Sachs (1998a and 1998b) and Wade and Veneroso (1998) argue that the crisis began with a mild panic that had no real foundation and was made serious only by IMF pressure to increase interest rates and to close down banks. Krugman (1998) presents a third theory based on international bank behavior by arguing there was a "Pangloss equilibrium" that caused a bubble in asset prices. In his view, the Asian panics had their origins in implicit (and implausible) guarantees offered by governments and believed by investors.

These explanations agree that for some reason, perhaps unrelated to economic fundamentals, there was a loss of confidence by domestic and foreign investors in all emerging markets. This led to a fall in capital inflows and an increase in capital outflows that triggered, in some cases, a very large nominal depreciation and a stock market crash. At the same time, these explanations do not address exactly why this loss of confidence had such large effects on the exchange rate and stock market in some emerging market countries but not others.

This paper presents evidence that the weakness of legal institutions for corporate governance had an important effect on the extent of depreciations and stock market declines in the Asian crisis. By "corporate governance" we mean the effectiveness of mechanisms that minimize agency conflicts involving managers, with particular emphasis on the legal mechanisms that prevent managers from expropriating minority shareholders (see Shleifer and 
Vishny 1997a). The theoretical explanation is simple and quite complementary to the usual macroeconomic arguments. If stealing by managers increases when the expected rate of return on investment falls, then an adverse shock to investor confidence will lead to increased theft and to lower capital inflow and greater attempted capital outflow for a country. These, in turn, will translate into lower stock prices and a depreciated exchange rate. In the case of the Asian crisis, we find that corporate governance provides at least as convincing an explanation for the extent of exchange rate depreciation and stock market decline as any or all of the usual macroeconomic arguments.

The Bangkok Bank of Commerce provides a well-documented case of expropriation by managers that worsened as the bank's financial troubles deepened. ${ }^{\square}$ The experience of creditors in Hong Kong who lent to firms doing business in mainland China is similar - Hong Kong-based company liquidators are not able to recover assets of Chinese companies that default on loans (Wall Street Journal, August 25, 1999, p.A14.) More generally, very few debt defaults from the Asian crisis of $1997-98$ have resulted in investors receiving any liquidation value. ${ }^{2}$ During the crisis, Korean minority shareholders protested the transfer of resources out of large firms, including Samsung Electronics and SK Telecom. Most collapses of banks and firms in Russia after the devaluation of August 1998 were associated with complete expropriation; creditors and minority shareholders got nothing (Troika Dialog 1999). Table 1 summarizes the details of leading allegations of expropriation in countries affected by the Asian crisis. Note that in many

\footnotetext{
1 "As the losses mounted, Thai authorities say, more and more money was moved offshore, much of it through a now-defunct Russian bank run by one of Mr. Saxena's business partners. Mr. Saxena's activities, says Mr. Aswin [who was brought in later to save the bank], "came to look like straight siphoning" (The Wall Street Journal 1999, p.A6.)

${ }^{2}$ For example, The Economist reports "Despite the creation last year of a bankruptcy law in Indonesia where there had been none before, it is still virtually impossible to force a defaulted debtor into liquidation (the few creditors that have tried are still tangled up in legal appeals)" (30 January 1999).
} 
of these cases, controlling shareholders did not need to break any local laws in order to expropriate investors.

In most of these instances, management was able to transfer cash and other assets out of a company with outside investors. These assets may have been used to pay the management's personal debts, or they may have been used to shore up another company with different shareholders, or they may have become straight capital flight into a foreign bank account. The fact that management in most emerging markets is also the controlling shareholder makes these transfers easier to achieve. The downturns in these countries have been associated with significantly more expropriation of cash and tangible assets by managers.

Our results highlight the importance of the legal protection afforded creditors and minority shareholders and are closely linked to the recent findings of La Porta, Lopez-de-Silanes, Shleifer, and Vishny 1997, 1998, and 1999b (hereafter referred to as LLSV). These authors show that the extent to which creditor and minority shareholder rights are protected explains a great deal of the variation in how firms are funded and owned across countries. In particular, LLSV (1997) provide evidence from a sample of 49 countries that weak shareholder rights and poor enforcement leads to underdeveloped stock markets. Here we show that weak enforcement of shareholder rights had first-order importance in determining the extent of exchange rate depreciation and stock market collapse in 1997-98.

Related ideas have been expressed by Yellen (1998), Rajan and Zingales (1998), and Caballero and Krishnamurthy (1998). Yellen (1998) argues that "a 'relationships' model of capital allocation is extraordinarily susceptible to a deterioration in perceptions about the quality of investment decisions." Rajan and Zingales (1998) explain the problems that can occur when a relationship-based financial system is opened up to capital inflows. Caballero and 
Krishnamurthy (1998) emphasize the underinvestment in appropriate collateral that occurs due to incentive problems.

Section 2 presents the assumptions and implications of our model. Section 3 explains our sources and data on exchange rate depreciation and stock market declines during the "Asian crisis." Section 4 briefly assesses the ability of standard macroeconomic measures to explain the magnitude of depreciation in 1997-98. Section 5 shows that measures of corporate governance provide a better explanation for the extent of exchange rate depreciation, and Section 6 assesses both macroeconomic and corporate governance explanations for stock market performance in 1997-98. Section 7 concludes by evaluating the relative strength of corporate governance and macroeconomic explanations for what happened in the Asian crisis.

2. Stealing and Speculative Attacks

\section{A Simple Static Model}

Consider the following simple model. $\mathrm{B}$ The manager owns share $\alpha$ of the firm and outsiders own share 1- $\alpha$. Retained earnings are denoted by I. The manager steals $S \geq 0$ of retained earnings and obtains utility of S from them. ${ }^{-}$Stealing is costly and the manager expects to lose $C(S)=\left(S^{2} / 2 k\right)$ when he steals because, for example, other people need to be paid off and there is some probability that the manager will be caught and punished. A higher value of $\mathrm{k}-$ representing, in this case, weaker corporate governance rules or a weaker legal system or both -

\footnotetext{
${ }^{3}$ This model is related to LLSV (1999b), although they assume a different timing for expropriation relative to investment. As in Jensen and Meckling (1976) the conflict of interest is between insiders (managers) and outsiders (equity owners in our simple model.)

${ }^{4}$ We use "stealing" as shorthand for more general forms of expropriation by managers. A referee has pointed out that we could cast the model in terms of general agency problems for managers (e.g., shirking). Our results apply directly to any managerial agency problems that become worse in an economic downturn. Note that many forms of stealing are actually legal in countries with weak legal environments.
} 
means that it is less costly to steal. Thus the value of stealing, $\mathrm{S}-\mathrm{C}(\mathrm{S})$, is concave in $\mathrm{S}$. The marginal value of stealing falls as the amount stolen increases because it becomes harder to steal as the absolute amount of theft increases. For example, the stealing becomes more obvious and easier for a court to stop.

The manager invests what he does not steal in a project that earns a gross rate of return R, which is greater than one, and from which he obtains the share $\alpha$ of profits. The manager's optimization problem is given by:

$$
\operatorname{Max}_{S} U(S ; R, k, \alpha)=\operatorname{Max}\left[\alpha R(I-S)+S-\left(S^{2} / 2 k\right)\right]
$$

and the optimal amount of theft, $\mathrm{S}^{*}$, is found by solving:

$$
\partial \mathrm{U} / \partial \mathrm{S}=1-\left(\mathrm{S}^{*} / \mathrm{k}\right)-\alpha \mathrm{R}=0,
$$

which yields,

$$
\mathrm{S} *(\mathrm{R}, \mathrm{k}, \alpha)=\mathrm{k}(1-\alpha \mathrm{R})
$$

We assume that the parameter values are such that the manager will not attempt to steal more than the total amount of retained earnings: $S^{*}(\mathrm{R}, \mathrm{k}, \alpha) \leq \mathrm{I}$. This simplifies the analysis by avoiding a corner solution, without changing the main insights.

The manager equates the marginal cost and marginal benefit of stealing. Because the manager owns $\alpha$ of the firm, he has an incentive to invest at least some of the firm's cash rather than to steal it all. As $\alpha$ rises, the equilibrium amount of stealing falls. As $\mathrm{k}$ rises, the amount of stealing in equilibrium rises. If $\alpha>1 / R$, the manager's stealing is "negative," meaning the manager puts in some of his own money into the firm; for our purposes, we assume that $\alpha$ is low enough that he chooses to steal.

\footnotetext{
${ }^{5}$ We could also assume that the manager is credit constrained. In this static model, assuming that the manager never steals less than zero does not substantially alter the analysis. In a dynamic model we can relax this assumption to allow the manager to have "negative" stealing (putting his own money into the
} 
Differentiating the optimal stealing equation with respect to R gives:

$$
(\partial \mathrm{S} * / \partial \mathrm{R})=-\alpha \mathrm{k} .
$$

An increase in the rate of return on the invested resources reduces the amount of stealing, because it raises the marginal opportunity cost of the stolen resources.

A larger $\alpha$ means $\partial \mathrm{S} * / \partial \mathrm{R}$ is more negative. If the manager owns more of the firm, then a given increase in the return on investment convinces him to put more resources into the investment project and, therefore, to steal less. Conversely, if the manager owns more but the return on investment declines, then he steals more.

A larger value of $\mathrm{k}$ means that $\partial \mathrm{S}^{*} / \partial \mathrm{R}$ is more negative. A lower cost of stealing (higher k) both raises the equilibrium value of stealing and makes stealing more responsive to changes in the rate of return on investment. This is because higher $\mathrm{k}$ both shifts up the stealing function and makes it less concave (i.e., the returns to stealing do not decrease so strongly.)

The outside investor receives share (1- $\alpha)$ of the returns from the funds that are actually invested in the firm. The expected value of the equity in the firm is therefore:

$$
\Pi=\mathrm{R}(\mathrm{I}-\mathrm{k}(1-\alpha \mathrm{R})),
$$

where $\Pi$ is the equity value of the firm. This is the value of all the equity, held by both outsiders and managers, which equals the total value of the firm minus the value of stealing.

Differentiating with respect to R gives the "absolute responsiveness,"

$$
\rho_{\mathrm{a}}=\partial \Pi / \partial \mathrm{R}=\mathrm{I}-\mathrm{k}+2 \mathrm{R} k \alpha
$$

firm) this period in order to keep the firm alive and enjoy "positive" stealing in the future (Friedman and Johnson 1999.) 
which is the sensitivity of firm value to changes in $\mathrm{R}$. This is always positive because we have assumed that the optimal level of stealing is less than I.

There are two effects of a higher R. The first, direct effect is to raise the expected payoff and thus increase the amount that the investor is willing to put into the firm. Holding the level of stealing constant, the direct effect shows that the value of the firm rises. The second, indirect effect works because higher returns from investment reduce the optimal level of stealing, so $\partial \mathrm{S} * / \partial \mathrm{R}<0$. Lower stealing also raises the expected payoff for outside investors and increases the value of the firm.

What is the effect on $\partial \Pi / \partial \mathrm{R}$ of changing the penalty for managerial theft, $\mathrm{k}$ ? The effect on the absolute responsiveness is

$$
\partial \rho_{\mathrm{a}} / \partial \mathrm{k}=2 \mathrm{R} \alpha-1
$$

For low values of $\alpha \mathrm{R}$, such that $\mathrm{R} \alpha<1 / 2$, a higher value of $\mathrm{k}$ (a lower penalty) implies a fall in $\partial \Pi / \partial \mathrm{R}$. For high values of $\alpha \mathrm{R}$, however, a higher value of $\mathrm{k}$ implies an increase in $\partial \Pi / \partial \mathrm{R}$. The intuition for this result is that when $\alpha \mathrm{R}$ is small the manager is already stealing a great deal, so $\Pi$ is already low in absolute terms and further changes in $\mathrm{R}$ do not induce much additional theft. ${ }^{\text {B }}$

\footnotetext{
${ }^{6}$ The maximum value of stealing, given by the first order condition when $\alpha \mathrm{R}$ is zero, is $\mathrm{k}$. We already assumed that there cannot be "negative" stealing, so $\mathrm{k} \leq \mathrm{I}$, and this is sufficient to ensure that $\rho_{\mathrm{a}}>0$.

${ }^{7}$ In order to make the main point, we have presented a simplified model that ignores general equilibrium effects. Assuming $\alpha$ is exogenous, the expected return for an outside investor varies between countries that have a different value of $\mathrm{k}$. In equilibrium this would not occur because outside investors would want to invest more in the country with a higher return. A complete model would include these general equilibrium effects.

${ }^{8}$ Differentiating absolute responsiveness with respect to $\mathrm{k}$ gives:

$$
\partial \rho_{\mathrm{a}} / \partial \mathrm{k}=\partial^{2} \Pi / \partial \mathrm{R} \partial \mathrm{k}=(-\partial \mathrm{S} / \partial \mathrm{k})+\left[-\mathrm{R}\left(\partial^{2} \mathrm{~S} / \partial \mathrm{R} \partial \mathrm{k}\right)\right]
$$

The first term is always negative: a higher value of $\mathrm{k}$ increases the absolute level of stealing. But the second term is positive - when $\mathrm{k}$ is higher, a given change in $\mathrm{R}$ induces a smaller change in the level of stealing (due to the convex stealing costs). When the second term is relatively large in absolute terms, i.e., when $R$ is high, then $\partial^{2} \Pi / \partial R \partial k$ will be positive.
} 
However, we can obtain an unambiguous comparative static prediction for the relative responsiveness,

$$
\rho_{\mathrm{r}}=(\partial \Pi / \partial \mathrm{R}) / \Pi=(\mathrm{I}-\mathrm{k}(1-\alpha \mathrm{R})+\mathrm{Rk} \alpha) / \mathrm{R}(\mathrm{I}-\mathrm{k}(1-\alpha \mathrm{R}))
$$

which is the sensitivity of firm value in percentage terms. The derivative of this change with respect to $\mathrm{k}$ is:

$$
\partial \rho_{\mathrm{r}} / \partial \mathrm{k}=\mathrm{I} \alpha /(\mathrm{I}-\mathrm{k}+\mathrm{Rk} \alpha)^{2}>0
$$

This effect is positive regardless of the value of $\alpha .{ }^{6}$ A higher value of $k$ (i.e., a weaker legal environment) implies that $(\partial \Pi / \partial \mathrm{R}) / \Pi$ increases, so that the value of the firm, $\Pi$, becomes more sensitive in percentage terms to a change in the rate of return, $\mathrm{R} .{ }^{10}$ In the data, therefore, we will look at percentage changes in firms' values.

\section{Implications for the Exchange Rate}

Our model so far has dealt exclusively with the effect of a loss of confidence on the value of a single firm. Aggregating similar firms to create an economy-wide collapse of firms' values is straightforward. We can also reasonably assume that foreign investors and many domestic investors care about returns in dollars. We then have the result that a fall in $\mathrm{R}$, which is now a

\footnotetext{
${ }^{9}$ Note that the relationship between absolute and relative responsiveness is: $\partial\left(\rho_{\mathrm{a}}\right) / \partial \mathrm{k}=\partial\left(\Pi \rho_{\mathrm{r}}\right) / \partial \mathrm{k}=\Pi\left[\partial \rho_{\mathrm{r}} / \partial \mathrm{k}\right]+[\partial \Pi / \partial \mathrm{k}]\left(\rho_{\mathrm{r}}\right)$. The first term is positive. The second term contains $\partial \Pi / \partial \mathrm{k}$, which is negative. ${ }^{10}$ This same result holds if we allow firms to borrow debt as well as issue equity. However, as we showed in an earlier working paper, the presence of debt means, in general, that there exists a range of values for $\mathrm{R}$ within which a lower value of $\mathrm{R}$ actually means less stealing. The intuition is that the manager steals less (or may even transfer funds into the firm if that is possible) in order to enable the firm to service its debt and therefore preserve the possibility of future stealing. If R falls sufficiently low, however, then the manager will choose to loot the firm and it will go out of existence.
} 
loss of confidence about returns in dollars, can trigger a fall in firms' values in dollars (i.e., the value of the stock market in dollar terms). 11

But will such a collapse of firms' values occur alongside an exchange rate collapse? Theoretically, a sharp fall in stock prices need not affect the exchange rate. Outside investors may choose to bring more capital into the country if, for example, they are more patient than domestic investors. The exchange rate only depreciates if the loss of confidence about $\mathrm{R}$ also

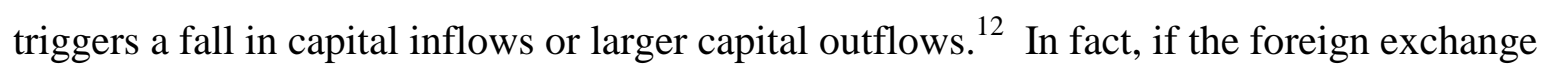
market is forward looking, the mere prospect of a reduction in net capital inflows should be enough to cause an immediate depreciation. There are five reasons why a loss of confidence may cause the net capital inflow to fall and why this fall may be larger when corporate governance is weaker.

First, when the expected return to outside investors is lower, investing in a country is less attractive. Outside investors receive less because the actual returns on investment projects are lower and because managers steal more. For a given level of expected risk, lower expected returns tend to reduce the net capital inflow to a particular country. ${ }^{13}$ Weaker corporate governance means lower short-term expected returns or more risk or both.

\footnotetext{
${ }^{11}$ Note that firms' values could fall sharply, even if there is not much actual stealing. The value of firms' to outsiders is determined by expected expropriation, or simply how much investors think managers will let them share in the returns on investment.

${ }^{12}$ Alan Greenspan (1998) explains the depreciation spiral and its spread across countries as follows: "The loss of confidence can trigger rapid and disruptive changes in the pattern of finance, which, in turn feeds back on exchange rates and asset prices. Moreover, investor concerns that weaknesses revealed in one economy may be present in others that are similarly structured means that the loss of confidence can be quickly spread to other countries."

${ }^{13}$ In a full model, investors would trade off risk and expected returns. If they learn that the expected return is lower, while risk is unchanged or has even increased, their preference for assets in this country will be reduced. This is one explanation for why many global investment funds cut their positions in emerging markets in 1997-98. See International Organization of Securities Commissions (1998) for a more detailed discussion.
} 
Second, there are important agency problem-based reasons why traders who have just lost a great deal of money cannot immediately invest more in a country, even if they believe the expected returns are high. Shleifer and Vishny (1997b) develop a model in which traders cannot persuade their financial backers that they should be allowed to invest more, because having lost money may indicate that the trader has bad judgment. ${ }^{4}$ In reaction to a fall in asset prices, financial backers may insist that the trader cut his or her position in a country even further. Shleifer and Vishny (1997b) make this argument for hedge funds involved in arbitrage, but the same argument can be applied to large international banks lending to countries. As these investors pull their money out, the exchange rate depreciates.

Third, there may be particular institutional reasons why commercial banks refuse to roll over their loans. This might be due to regulatory rules and procedures that limit a bank's "value at risk" (Cornelius 1999). When prices fall in a market, the value-at-risk models used by international banks can generate the direct requirement that the bank reduce its exposure to that country (Folkerts-Landau and Garber, 1998.) Unless the borrower defaults when the loans are not rolled over, this constitutes a capital outflow. Even if the borrower defaults, there will still be a reduction in new capital inflow. The details of value-at-risk models vary, but a bigger fall in asset prices, due to worse corporate governance, can plausibly trigger a larger reduction in the bank's investment position in all the assets of that country.

Fourth, when managers choose to steal more of the corporate cash, they may take the money outside the country. For this to happen, managers need to care about their returns in foreign currency terms. This may be because they have personal expenses in dollars or because

\footnotetext{
14 "The seemingly perverse behavior of taking money away from an arbitrageur after noise trader sentiment deepens, i.e., precisely when his expected return is greatest, is a rational response to the problem of trying to infer the arbitrageur's (unobserved) ability and future opportunities jointly from past returns," (Shleifer and Vishny 1997b, p.41.)
} 
they feel local-currency denominated assets, such as bank deposits, are not the right place to keep the proceeds of what they have stolen (e.g., because they want to avoid taxes.) Weaker corporate governance means that more is stolen for a given reduction in expected $\mathrm{R}$, leading to more capital flight and deeper currency depreciation.

Finally, as an important complement to the previous four explanations, there may be no safe haven for investors in local currency-denominated assets. Management of local commercial banks may also engage in theft, raising the probability that these banks will default. The government could guarantee bank deposits but in most emerging markets there is a significant risk that the government may default. In fact, in some emerging market countries, such as Indonesia and Thailand, there was no liquid market for government securities at the time of the crisis. In the view of many investors during the Asian crisis, the probability of government default went up as the value of firms and tax receipts went down. The only government that actually defaulted on domestic currency debt during the crisis was Russia, but a number of other governments appear to have come close. Thus when the value of firms began to fall in each emerging market country, both domestic and foreign investors tried to withdraw their money from all domestic-currency denominated assets, leading to greater capital outflows for countries with weaker corporate governance. Note that there can be a net capital outflow even if foreign investors remain confident. A loss of confidence in local currency-denominated assets by domestic investors can be just as damaging.

These arguments suggest that the extent of exchange rate depreciation may be affected by corporate governance institutions. As long as a larger fall in firms' values means that investors are less inclined to buy their securities, then capital can flow out of the country. The evidence in fact shows a sharp reduction in capital inflows to emerging markets after July 1997, turning into 
capital outflows by September (Brunswick Warburg 1999). $\frac{15}{{ }^{1}}$ Net capital inflows to emerging economies peaked at \$330bn in 1996 but fell to less than half that in the Asian crisis (Goldman Sachs, 1999, p.3).

\section{Corporate Governance and Volatility}

In our model, there need not be any actual expropriation by managers while times are good, for example when $\alpha \mathrm{R} \geq 1$. Typically, in most emerging markets $\alpha$ is above 0.3 (i.e., much higher than is usual in the US), so a reasonably optimistic expectation for R may be enough to remove the incentive for managerial theft. $\frac{16}{16}$

This suggests that the "institutions" that protect investors' rights are not important as long as growth lasts, because managers do not want to steal. It may even be possible to attract a great deal of outside capital during a period when the economy expands. But when growth prospects decline, the lack of good corporate governance becomes important. Without effective shareholder protection, a mild shock can entail a large increase in stealing, which in turn causes a large depreciation. 17

\footnotetext{
${ }^{15}$ The World Bank (pp.25-26, 1999) estimates that capital outflows from emerging markets increased by $\$ 80 \mathrm{~m}$ between 1996 and 1997. This source points out that we do not have precise estimates of capital flows, including capital flight, by country.

${ }^{16}$ Detailed examination of insider ownership in some emerging markets are in La Porta, Lopez-deSilanes, and Shleifer (1999) and LLSV (1999b). They find, for example, that the median cash flow rights (in companies where insiders control more than 20\% of the votes) are $41 \%$ in Argentina, 26\% in Korea, $28 \%$ in Hong Kong, 34\% in Mexico, $20 \%$ in Israel, and 31\% in Singapore.

${ }^{17}$ This explains, for example, how Malaysia could grow rapidly even if its institutions were flawed. In the following exchange, Prime Minister Mahathir argues that rapid growth implies that the institutions are good (The Far Eastern Economic Review, July 2, 1998, p.15.)

Question: So in retrospect nothing in your own policies was wrong?

Mahathir Mohamad (Prime Minister of Malaysia): We were growing at the rate of more than $8 \%$ a year for almost 10 years. You must give us credit for knowing how to run the country. And if you are so corrupt, nothing will be able to be done in this country.

This argument is incorrect because a corrupt economy can grow rapidly. Our model shows that institutions matter most when the economy experiences a downturn.
} 
According to this argument, a country can grow rapidly for an indefinite period even if it has weak protection for shareholder rights. But weak institutions of this kind make a country vulnerable, in the sense that a small negative shock to expected future earnings can have a large effect on the economy. If this theory is correct, institutions matter for volatility, specifically the size of the decline in asset values and exchange rate when there is an adverse shock to expected future earnings.

Our argument suggests two empirical issues to investigate. First, across countries where there was some initial loss of confidence, did the exchange rate depreciate more where corporate governance was weaker? We deal with this in section 5. Our simple model is silent on whether de facto or de jure shareholder and creditor rights matter more. We can test these alternatives by examining which kinds of rights were more important in determining the extent of exchange rate depreciation in 1997-98. Second, the model predicts that countries with poor corporate governance should also have weaker ex post stock market performance if we include the 1997-98 crisis. We examine the evidence on this point in section 6 .

\section{Data}

\section{Measuring the Crisis}

Our basic sample is 25 emerging markets: Argentina, Brazil, Chile, China, Colombia, the Czech Republic, Greece, Hong Kong, Hungary, India, Indonesia, Israel, Korea, Malaysia, Mexico, Philippines, Poland, Portugal, Russia, Singapore, Thailand, Turkey, Taiwan, South Africa, and Venezuela. The list includes 6 countries from Latin America, 4 from Eastern Europe, 10 from Asia, plus Greece and Portugal in Europe, Turkey, Israel in the Middle East, and South Africa. There is no universally agreed definition of the "emerging markets" involved 
in the Asian crisis, but our sample of 25 includes almost all the countries regarded as "emerging" by the International Finance Corporation, The Economist, JP Morgan, Goldman Sachs, and Flemings. This is the set of developing countries with relatively large financial markets and relatively open capital accounts. 18

We follow the literature on the Asian crisis by regarding the extent of the nominal exchange rate depreciation as the key variable to be explained. Specifically, our most important dependent variable is the change in the nominal exchange rate from the end of 1996 to January 1999. We take the end of 1996 as the starting point and measure the change in purchasing power over the next two years of currencies relative to the US dollar. ${ }^{19}$ Table 2 shows the exchange rates and change in purchasing power of exchange rates for alternative ending points for the 25 countries in our sample.

The crisis clearly began in summer 1997 with the initial devaluation of Thailand. However, there is no agreement on when the crisis ended. There were basically four phases: fall 1997, when the major problems were in Asia and a few countries in Latin America; spring 1998, when the crisis is perceived to have spread to Russia and Brazil; summer 1998, when Russia devalued; and fall 1998, when Brazil struggled against devaluation. The crisis from Brazil's

\footnotetext{
${ }^{18}$ According to IFC (1997, p.334) at the end of 1996 there was completely free entry and exit of capital (with regard to listed stocks) in 12 of our countries: Argentina, Brazil, the Czech Republic, Greece, Hungary, Malaysia, Mexico, Poland, Portugal, Russia, South Africa, and Turkey. There was also "relatively free entry" and free exit in Chile, Korea, Thailand, and Venezuela. There was "relatively free entry" and "some restrictions" on exit in Indonesia. Formally, there was free entry and exit only for special classes of shares in China and the Philippines, although the anecdotal evidence suggests these capital controls have only really been effective in China. Authorized investors only were allowed into Colombia and India, but free exit was allowed. The tightest market access, according to the IFC measure, was in Taiwan, where only authorized investors were allowed in and there were "some restrictions" on the repatriation of income and capital. The IFC did not classify Hong Kong, Israel, and Singapore.

${ }^{19}$ If the exchange rate depreciates from 2500 to around 10000 to the dollar (as in Indonesia), it has lost $3 / 4$ of its purchasing power - i.e. you need four times as many rupiah to buy one dollar. Alternatively, its purchasing power now is $1 / 4$ of the level one year ago and this country would get 0.25 in our index of change in purchasing power.
} 
point of view continued at least through the eventual devaluation in January 1999, although by this time most of the Asian countries were starting to recover (and their exchange rates were actually appreciating). All our regressions use mid-January 1999 as the ending point. None of our results are affected by including or excluding Brazil's January 1999 devaluation, and in an earlier working paper we also presented similar regression results using March 1998, July 1998, September 1998, November 1998 and April 1999 as alternative ending points. Table 2 presents the raw exchange rate data for these alternative dates. We report these robustness checks in more detail as we move through the analysis.

For stock markets, we use the International Finance Corporation's Investable Index (IFC 1998 and 1999 and updated daily in the Financial Times) which measures stock market returns for a selected set of companies in US dollars. This index includes the largest and most liquid stocks in each market. Using the IFC's Investable Index reduces the usual problem that posted prices in illiquid markets may not be real transaction prices. Table 3 reports the value of this IFC index at the end of each 1998 and at its lowest point in 1998, assuming that the value for each country was equal to 100 at the end of 1996. The IFC does not report an index for Hong Kong or Singapore, so we use the standard Hang Seng Stock Index and Straits Times Stock Index respectively, converted into US dollars.

Some countries began to show definite signs of economic recovery in the second half of 1998, just as other countries were experiencing the full effects of the crisis. For example, the Korean index we use reached a low point of 23.6 at the end of September, but had recovered to 53.1 by the end of the year. In our main regressions we therefore look at the lowest point in the stock market during 1998 to measure how far the market fell as a result of the crisis. We have also checked our results using the end of 1998 as an alternative end point. 
In terms of the model, our empirical tests assume that $\mathrm{R}$ and $\alpha$ are constant across

countries. We test whether $\mathrm{k}$, as measured by corporate governance variables, has an

independent impact. We feel this assumption is reasonable, to a first approximation because the

anecdotal evidence suggests there was a similar shock across all emerging markets. 20 We do not know if the size of this initial shock to confidence was exactly the same in all countries, but the evidence indicates both that the initial loss of confidence was small and that, at least in fall 1997, almost every emerging market was affected (International Monetary Fund 1997.)

\section{Measuring Economic Conditions}

To measure prior economic conditions we use standard macroeconomic aggregates (the raw data is in Table 3). We use the versions of this data published by two investment banks, JP Morgan (1997) and Goldman Sachs (1997). Both of these organizations build their databases using the available information from national statistical offices and international organizations, most notably the IMF and World Bank, but they also put a great deal of effort into ensuring that the data is comparable across countries. In addition, using these sources helps us examine whether information actually available to the financial markets before the crisis was useful in predicting the exchange rate. Following the suggestion of a referee, we fill gaps in this data using numbers from the World Bank and the IMF (details are in Table 3).

\footnotetext{
${ }^{20}$ For Asia see Biers (1998). For all emerging markets see Hunter et al (1999) - most of the essays in this book argue or assume there was a similar shock of some kind across all emerging markets.

${ }^{21}$ As a referee has pointed out, it is possible that the shock was larger in countries with weaker institutions, for reasons that are unrelated to institutions. However, there is no evidence of such a pattern to the shock. The anecdotal evidence suggests there was a small loss of investor confidence, beginning in Thailand, spreading to Asia and then suddenly including other emerging markets - marked by a surprising sell-off in Hong Kong from October 1997. By November 1997 there had been some small loss of confidence or questioning of future prospects in almost all emerging markets.
} 


\section{Measuring Institutions}

We use the measures for efficiency of the legal system, corruption, rule of law, and strength of corporate governance reported in LLSV (1998). Efficiency of the legal system is the assessment of an independent organization (Business International Corporation) of "the efficiency and integrity of the legal environment as it affects business." Corruption is an assessment by another independent organization (International Country Risk Services) of the extent of corruption in the government, particularly the extent to which businesses have to pay bribes. The rule of law is also an assessment by International Country Risk Services and is their opinion of the "law and order tradition" in the country (LLSV 1998, Table 1). Corporate governance is LLSV's (1998) assessment of the de jure rights of shareholders (particularly what they call "anti-director" rights). LLSV (1998) also provide measures of creditor rights. The final LLSV (1998) measure we use is their index of accounting standards. The raw data and precise definitions for all these measures are reported in Table 3.

All of these measures were calculated well before the Asian crisis. Efficiency of the legal system pertains to 1980-83. The measures of corruption and law and order cover 1982-95. The measures of corporate governance were calculated primarily using data for the early and mid1990s.

Flemings Research (1998) developed an alternative measure of corporate governance across emerging markets. They asked their country specialists to consider "the disclosure of information, transparency of ownership structures, management and special interest groups, adequacy of the legal system, whether the standards that are set are actually enforced, and if the boards of companies are independent and the rights of minority shareholders are upheld" (p.19). This index therefore tries to capture the extent of shareholder rights in practice. The index runs 
from 1 to 5 with a higher score meaning more rights and "a score of 5 would be awarded to the US - our model market." One disadvantage of this measure is that it was published in spring 1998, and therefore may reflect in part reassessments of shareholder rights in the light of the Asian crisis.

We test the importance of alternative measures of macroeconomic policy and institutional structure using regressions with change in the value of the nominal exchange rate on the lefthand side. We then test the leading contenders using additional control variables and in multiple regressions. Our regressions also include a dummy variable for being in East Asia, in case there was an Asian-specific element to the crisis (e.g., countries were affected just because they are close to each other or because they faced a different shock because they are in Asia).

Some of our regressions have less than 25 observations, because we usually lack comparable data on a few countries. We have checked the robustness of our results by using alternative samples, in particular so as to judge the macroeconomic and corporate governance variables using the same set of countries. Because we do not have a full set of corporate governance data for 5 transition economies, China, the Czech Republic, Hungary, Poland, and Russia, we also report summary results for the macroeconomic regressions without these five 5 countries.

\section{Macroeconomic Measures}

Much of the debate over the Asian crisis has focussed on the relative importance on five macroeconomic variables: the budget deficit, monetary policy, the current account, foreign

\footnotetext{
${ }^{22}$ The East Asia dummy is equal to one for China, Hong Kong, Indonesia, Korea, Malaysia, Philippines, Singapore, Thailand, and Taiwan. We do not include India because it seems that financial markets regarded India as part of South Asia, and distinct from East Asia. Nothing substantive changes if we
} 
exchange reserves, and foreign debt. The raw data for these measures are presented in Table 3 . The dependent variable used in this section is the percent loss of purchasing power of exchange rates in emerging markets in from the end of 1996 to January 1999.

\section{Fiscal and Monetary Policy}

Table 3 shows government fiscal balance as a percent of GDP in 1996 for 25 countries (a minus sign indicates a budget deficit). It is striking that Indonesia had a balanced government budget and none of the Asian countries that experienced a large depreciation had a serious fiscal deficit. Not surprisingly, the first two columns of Table 4 show the government budget deficit is not significant in the exchange rate regression, either by itself or with the inclusion of the East Asia dummy. The R-squared is 0.09 before we include the East Asia dummy and rises to only 0.1 with that dummy.

In the standard theory of balance of payments crises (Krugman 1979), the budget deficit should affect the exchange rate through affecting the money supply. Even if budget deficits have no discernible direct effect, perhaps there is an impact via money growth? Table 3 shows the growth rate of broad money in 1996 for 25 countries. It is just significant in the exchange rate regressions at the $10 \%$ level with or without the East Asia dummy (columns three and four of Table 4), when we drop Turkey, which is an extreme outlier with $120 \%$ money growth. With Turkey in the sample, broad money growth is significant and negative at the 5\% level.

This result should be treated with care because of the countries with large depreciations, only Russia had significant budget deficit-induced money growth. Indonesia had high money

allow the Asian dummy to include India. This dummy can also partly capture the notion that there was herding in the idea that investors should "sell Asia." 
growth in 1996 and a large depreciation in 1996-98, but its budget was essentially balanced before the crisis. If we drop Indonesia and Turkey, money growth in 1996 is not significant.

\section{Current Account and Reserves}

The current account as a percent of GDP in 1996 is shown in Table 3 with 25 observations. There are two outliers with a very high current account surplus: Singapore and Venezuela. This measure of the current account is not significant in explaining the exchange rate depreciation by itself (Table 4). Even if we drop Singapore and Venezuela, the two outliers, there is no significant result using the current account as an explanatory variable.

If the exchange rate collapses involved a loss of confidence by investors, irrespective of macroeconomic fundamentals, we would expect reserves of foreign exchange at the central bank to be significant explanatory variables. Countries with more reserves should be able to withstand an outflow of capital or speculation against their currency.

The simplest measure is just total reserves in dollar terms. We use total reserves in US dollars for 25 countries at the end of 1996; see Table 3. Table 4 shows total reserves are not quite significant at the $10 \%$ level in the basic regression but with the East Asia dummy included they become significant at the $5 \%$ level. The adjusted R-squared is 0.1 . The quantitative effect of higher reserves is small: $\$ 10 \mathrm{bn}$ extra reserves implies four percent less depreciation in the exchange rate from 1997 to 1998 (in addition to the effect of being in East Asia). This suggests that only in countries with huge reserves, such as China, Taiwan, Singapore, and Hong Kong, was there really a significant impact on the exchange rate from holding more reserves.

Table 3 shows the months of imports ("import coverage") provided by reserves in 25 countries. There is a positive correlation in the regression, significant at the $5 \%$ level without the 
East Asia dummy and at the $10 \%$ with this dummy, meaning that a higher degree of import coverage is associated with less depreciation (Table 4). The adjusted R-Squared is 0.12 . For a country such as China, which held almost 10 months worth of reserves, there is a large positive effect relative to Korea, which held under 2 months worth.

\section{Foreign Debt}

There is a general view among economists that Asian countries must, in some sense, have over-borrowed. Yellen (1998) puts the point clearly, "Since short-term loans by definition expire relatively quickly, massive short-term lending at low risk premia is precisely the combination of factors most likely to lead to a sudden and massive capital flight."

There are several reasonable ways to measure foreign indebtedness. We can look at total debt directly or, alternatively, we can assess the "debt burden" of an economy by comparing debt relative to the size of the economy or its ability to generate foreign exchange earnings through exports. We can also consider the maturity structure of the debt, interest payments as a percent of exports, and the ratio of debt to GDP. All the debt numbers here include both public and private debt (to the extent it is known) denominated in foreign currency.

The simplest measure of external debt is the total dollar amount of indebtedness, both public and private, of a country. According to the available numbers for 25 countries in our sample, at the end of 1996 Brazil had a high level of indebtedness, with nearly $\$ 200 \mathrm{bn}$, while Russia and Indonesia both had around $\$ 120 \mathrm{bn}$ (Table 3). Total indebtedness is insignificant in our exchange rate regressions both without and with the East Asia dummy (Table 4). This variable is insignificant even if we drop Hong Kong, which had the highest level of gross 
indebtedness. ${ }^{2.3}$ We look at four other reasonable foreign debt measures: as a percent of exports, short-term debt plus amortization as a percent of reserves, interest payments as a percent of exports, and the Debt-GDP ratio. None are significant in the regressions reported in Table 4.

\section{Robustness Checks}

We have not found any specification in which combinations of macroeconomic variables have stronger effects than individual variables. Combining other macroeconomic variables with measures of reserves, for example, usually reduces the significance of the reserves.

We constructed a composite variable measuring foreign debt net of foreign exchange reserves. The result for this variable is weaker than that for reserves, presumably because while total level of foreign exchange reserves has a strong effect, total debt has a weak effect, so by putting them together we are constructing a weaker variable that is only marginally significant in the exchange rate regression.

We have also controlled for the size of rescue packages offered to various countries between July 1997 and October 1998. The total amount of funds pledged, in US dollars, was $\$ 42.3$ billion to Indonesia, $\$ 58.2$ billion to Korea, $\$ 17.2$ billion to Thailand, $\$ 22.6$ billion to Russia, and \$41.0 billion to Brazil (The World Bank 1999, p.91, Table 3.2.). A bigger rescue package (in terms of funds pledged) is actually correlated with more depreciation, but this may be an endogenous outcome, in the sense that more money may have been given to those countries more likely to fail. Including this variable does not affect the significance of any of the macroeconomic variables.

\footnotetext{
${ }^{23}$ Gross indebtedness numbers for Hong Kong and Singapore are not available from the World Bank but rather from investment banks' research reports. We do not think that these numbers were calculated and published until after the crisis broke, so we have checked all our results without both Hong Kong and Singapore. Nothing substantive is changed.
} 
The funds actually disbursed during 1997-98 in these rescue packages were substantially less than the amounts pledged: $\$ 9.5$ billion to Indonesia, $\$ 27.2$ billion to Korea, $\$ 12.7$ billion to Thailand, $\$ 4.5$ billion to Russia, and $\$ 8.6$ billion to Brazil (The World Bank 1999, p.91, Table 3.2.) The amount of the rescue package actually disbursed is not significantly correlated with the extent of exchange rate depreciation, presumably because only countries that perform relatively well actually receive money. Again, including this variable does not affect the significance of the other macroeconomic variables.

Note that both receiving a pledge of financial assistance and having loans actually disburse are both endogenous outcomes rather than exogenous factors. The results using this variable are driven primarily by the large depreciation of Russia and Indonesia.

Our sample period ends just before Brazil's devaluation. However, even if we extend our sample period through late January 1999 (to capture the initial sharp devaluation) or April 1999, to include the first three months of a more freely floating exchange rate in Brazil, this does not help any of the macroeconomic variables to become significant. The reason is that although Brazil had current account and budget deficits in 1996, its final devaluation was not large compared to some other emerging market countries. Brazil experienced a 37 percent devaluation from the end of 1996 through April 1999, which is about the same as in Thailand and Malaysia and much less than in Indonesia or Russia (Table 3). This is not enough to change the outcome for any macro variable in the regression analysis. Interestingly, the lack of total collapse in Brazil, despite the poor initial macroeconomic fundamentals, is very much in line with what could have been predicted using the governance results from the next section. 


\section{Corporate Governance}

\section{Enforceability of Contracts}

We evaluate four measures of how easy it is to enforce contracts between management and the providers of firms' finance. The first three measures are general assessments of the legal environment: the efficiency of the judiciary, corruption (which includes bribing the judiciary and other branches of the government), and the rule of law. The fourth measure is a general assessment of corporate governance.

Judicial Efficiency measured on a scale of 0 to 10 is shown in Table 3, with 20 observations (not including any post-communist countries) from Business International Corporation, as cited by LLSV (1998). Indonesia easily has the worst score (2.5), while Hong Kong, Israel, and Singapore have the best (10). As Figure 1 shows there is a wide dispersion of values both within Asia and across emerging markets in general. This variable is highly significant in the exchange rate regression with and without the East Asia dummy (columns 1 and 2 of Table 5), and remains significant even if we drop Indonesia. Judicial Efficiency becomes significant at the 5\% level if we control for foreign exchange reserves (shown in Table 5) or import coverage (not shown in Table 5) and significant at the $6 \%$ level if we include both macro variables. Neither of these macroeconomic control variables is significant either separately or jointly in a regression with judicial efficiency.

The quantitative effect of Judicial Efficiency is large. A one-point increase in this index (the difference between Malaysia and Singapore, or slightly larger than the difference between Korea and Taiwan) implies a 5-6\% less depreciation from the end of 1996 to the end of 1998. The adjusted R-squared is 0.31 without the East Asia dummy, 0.29 with the East Asia dummy, and 0.28 with foreign exchange reserves included in the regression. 
Figure 2 shows corruption as measured by the International Country Risk Guide, and reported by LLSV (1998), on a scale of 0 to 10 , for 23 countries. This variable is highly significant and remains so when we include the East Asia dummy. A one-point increase in this index (meaning lower corruption, again approximately the difference between Malaysia and Singapore) implies 5\% less depreciation from the December 1996 to December 1998. The adjusted R-squared is 0.21 with and 0.2 without the East Asia dummy. When we control for foreign exchange reserves, the corruption variable remains significant at the $6 \%$ level and the foreign exchange reserves variable is not significant. The adjusted R-squared rises only slightly to 0.25 . If we control for import coverage separately or jointly with reserves, the corruption variable is significant at the $5 \%$ level and the macroeconomic control variables are not significant.

The third index is the Rule of Law, again from the International Country Risk Guide as reported in LLSV (1998) for 23 countries (see Figure 3). Table 5 shows that this variable is significant with and without the dummy variable for East Asia. A one-point increase in this index implies 4\% less depreciation from the end of 1996 to the end of 1998. The adjusted R-squared is 0.15 without the East Asian dummy and 0.12 with that dummy. The R-squared is 0.27 once we include the foreign exchange reserve variable, and in that case none of the variables is significant (but they are jointly significant at the 5\% level). The same is true if we use import coverage instead of reserves (now they are jointly significant at the $10 \%$ level.) If we include both reserves and import coverage, none of the right-hand side variables is significantly jointly or separately.

The fourth index is Corporate Governance as measured by Flemings' experts on particular countries. Their results for 20 countries in our sample are shown in Figure 4. This 
variable is significant at the $5 \%$ level with and without the East Asia dummy. It remains significant at the 5\% level when we also control for reserves (see the last column of Table 5). A one-point increase in this index implies 13-14\% less depreciation from the end of 1996 to the end of 1998. The adjusted R-squared is 0.26 without the East Asian dummy, 0.22 with the East Asia dummy, and 0.17 once we include the macroeconomic variables. If we control for import coverage either separately or together with reserves, corporate governance remains significant at the $10 \%$ level and neither of the macro variables is significant.

\section{Shareholder Rights}

LLSV (1998) also provide a number of more detailed indices for particular aspects of corporate governance: shareholder rights, creditor rights, and accounting standards. Data on shareholder or "anti-director" rights is available for all the countries in our sample, except the

five transition economies. Data on creditor rights are not available for the five transition economies and Venezuela. Data on accounting standards are not available for the five transition countries and Indonesia.

We look at each measure in turn and also evaluate the product of these rights and three measures of contract enforceability. Rights on paper may be good, but we are particularly interested in evaluating the implications of how these rights are enforced. We use a very simple measure, the product of legal de jure rights and the enforceability of these rights. Because it is hard to know exactly how rights are enforced we use the three indices of general legal environment used in the previous section: judicial efficiency, corruption, and the rule of law. This enables us to check for a robust pattern in the data. 
Table 3 shows the LLSV (1998) aggregate index of minority shareholder rights, on a scale of 0 to 6 , which they call "anti-director" rights. Asian countries show a wide range of values, with lower scores in countries that have experienced greater depreciation: Indonesia scores a 2 on this index, while Malaysia scores a 4 and Hong Kong scores a 5. On the other hand, Mexico and Venezuela, with much less depreciation, have even lower scores than Indonesia.

Table 5 shows that this variable is significant at the $10 \%$ level with and without the East Asia dummy. A one-point increase in this index implies a 6 percent smaller depreciation from 1997 to 1998 . The R-squared is 0.13 . When we include foreign exchange reserves, the index of shareholder rights keeps its significance at the $10 \%$ level and reserves are not significant. Including import coverage gives the same result: shareholder rights are significant at the $10 \%$ and the macro control variable is not significant.

For the product of anti-director rights and judicial efficiency, we find the regression coefficient is significant in all three of the usual specifications. The adjusted R-squared is consistently $0.22-0.23$. Using the product of anti-director rights and corruption or the product of anti-director rights and the rule of law gives similar results. Using import coverage rather than reserves does not make the governance variable insignificant in any specification, and in one case (corruption $\mathrm{x}$ anti-director rights), the effect is to make the governance variable significant at the $5 \%$ level.

The LLSV (1998) index of creditor rights shows that several countries with relatively high creditor rights had a great deal of depreciation, for example Indonesia, Malaysia, Thailand, and Korea (Table 3). Table 5 shows there is no significant relationship between creditor rights and the exchange rate depreciation; the R-squared is only 0.003 . The product of creditor rights 
and the efficiency of the judiciary or the corruption index does not give a significant result. There also does not appear to be any kind of relationship between the exchange rate depreciation and accounting standards (Table 5).

\section{Robustness Checks}

We have checked our results using money growth in 1996 as an alternative macroeconomic control variable. It we drop Turkey, then the legal environment (judiciary, rule of law and corruption) variables remain significant at close to their original levels (the corruption variable slips slightly) and money growth is not significant. The only variable to lose its significance is the index of anti-director rights. If we include Turkey, all the corporate governance variables, except anti-director rights, remain significant and money growth is significant at the 5 percent level.

We also included a dummy variable for Latin America which is 1 for Argentina, Brazil, Chile, Colombia, Mexico and Venezuela in our sample. This does not affect the significance of any of the governance variables and is itself insignificant in all the exchange rate regressions. The Latin America dummy is negative, with a coefficient of around -30 in the stock market regressions, but the only effect on governance variables is to make corruption insignificant. Total reserves become positive and significant in the stock market regression; the other results for macroeconomic variables are not affected.

Our earlier working paper reported results using a shorter sample period, ending in March 1998 or August 1998 or September 1998. The same corporate governance results held also for those periods. Controlling for the size of IMF packages, either pledged or actually disbursed, does not affect the significance of the governance variables. Controlling for combinations of 
macroeconomic variables also does not make any of our governance variables insignificant. (These results were in our earlier working paper and are available from the authors.)

The percent depreciation of the exchange rate plus the nominal interest rate at a moment in time is an alternative dependent variable (thanks to Ricardo Caballero for this suggestion). This captures the possibility that a country faces strong pressure to devalue, but is able to hold off the inevitable for a while through raising interest rates very high. Previous drafts of this paper showed that all of our corporate governance measures are significant with the right sign using this measure, calculated at moments of crisis such as September and November 1998, so this actually strengthens our results. The only macroeconomic variable that is significant in this regression is total foreign exchange reserves. When we combine these macro and governance measures, the governance results remain strong while foreign exchange reserves become insignificant. The robust result is that governance measures are correlated with the intensity of the exchange rate depreciation.

A referee suggested that we should control for log GDP per capita in 1994, as a measure of non-finance related institutional development. In this case, the efficiency of the judiciary variable loses its significance. However, the corruption, rule of law variables, corporate governance, are jointly significant with log GDP per capita (none of the variables are individually significant.) The anti-director rights variable remains significant at the $10 \%$ level by itself. The other governance variables lose their individual significance but are highly significant jointly with log GDP per capita. There is a high level of correlation between log GDP per capita and judicial efficiency (0.7) and rule of law and corruption, but low correlation with anti-director rights (0.05 and not significant). These results suggest that while corporate governance variables 
have some effects independent of the level of non-financial institutional development, there is also substantial overlap. 24

\section{The Stock Market}

\section{Macroeconomic Measures}

The dependent variable is the change in stock market value in dollar terms (as measured by the International Finance Corporation's IFC Investable Index) from the end of 1996 to the lowest point of 1998 and to the end of 1998. ${ }^{25}$ Table 3 shows the values of this index that we use.

Our regression analysis using macroeconomic variables shows very little correlation with stock market performance (Table 6). We report results for four variables that represent the key macroeconomic issues: the current account at the end of 1996, the level of reserves at the end of 1996, the debt-GDP ratio at the end of 1996, and the budget deficit in 1996. None of the first three variables are significant in any specification. Import coverage and other measures of debt are also not significant. Table 6 reports results using the lowest point of 1998 (see Table 3 for the month in each case); none of the results is changed significantly if we use the end of 1998.

A larger initial budget deficit is correlated with less depreciation. This implies that countries with a larger budget surplus (or smaller budget deficit) at the end of 1996 had worse stock market performance in the crisis. For example, a one-percent "better" budget implies a 5 percent lower stock market from the end of 1996 to the lowest point in 1998.

\footnotetext{
${ }^{24}$ For more on the correlation between corporate governance and other measures of institutional development, see LLSV 1999a.

${ }^{25}$ A comparison in dollars is appealing because this is how most international investors and the IFC evaluate stock market performance. Obviously, the dollar value of markets is heavily influenced by exchange rate movements. However, the correlation is not one to one.
} 


\section{Corporate Governance}

In contrast, the results using our legal variables are much stronger (see Table 7). The Judicial Efficiency variable is not significant, but the other legal environment variables are significant in most specifications.

Corruption, plotted against stock market performance in Figure 5, is significant both by itself and with the East Asia dummy. The regression coefficient implies that a one-point improvement in the corruption index is associated with $7.6 \%$ better cumulative stock market performance. The adjusted R-squared is 0.09 without the East Asia dummy. Corruption becomes more significant and has a larger coefficient when we control for reserves, but it is insignificant when we include both reserves and the East Asia dummy.

The rule of law variable is significant in 3 out of 4 specifications. It is not significant by itself but significant at the $5 \%$ level when we also control for reserves. This coefficient implies that a one point better score on the rule of law index is associated with 10 percentage points better stock market performance. The coefficient declines to just over 7 and the significance level falls to $10 \%$ when we control for East Asia and when we include both the East Asia dummy and reserves.

The corporate governance variable is significant until we bring in the East Asia dummy. The coefficient is over 12 and the R-squared rises to 0.22 when we include reserves. Interestingly, with the East Asia dummy included, reserves have the right sign: an extra 10 billion dollars of reserves implies a $4 \%$ better stock market performance. However, this is the only significant stock market result for reserves. 
Neither anti-director rights nor accounting standards are significant in the stock market regressions, even if we multiply these measures with the indices representing legal institutions. Creditor rights actually have a significant negative coefficient in the stock market regression for 1997-98, implying that countries with better protection for creditors experienced worse stock market performance, although this coefficient loses its significance when we include the East Asia dummy.

\section{Robustness Checks}

Using December 1998 as the ending point for our sample does not change the essence of the results. The macroeconomic variables are still not significant, with the exception of the fiscal policy variable, which consistently has the wrong sign. The same three legal variables remain robustly significant.

Controlling for money growth in 1996 does not affect the results. Corruption and corporate governance remain significant, as does the rule of law (if we also include reserves). Money growth is not significant in any specification. The same results hold if we control for money growth while dropping Turkey.

If we control for log GDP per capita and reserves in the corruption regression, the independent variables are jointly significant, but none of the variables are individually significance. In the same regression for rule of law, only the level of reserves is significant (but with a negative sign.) Judicial efficiency, the Flemings corporate governance measure, and the measure of anti-director rights are not significant. Log GDP per capita is significant in several specifications and given that it is highly correlated with the general legal environment, it may be picking up the strength of some institutions (although probably not anti-director rights). 
The stock market results for measures of investor protection are more dependent on outliers than is the case for our exchange rate results. In particular if we drop Indonesia, the rule of law result is unchanged, but corruption and the corporate governance variable lose their significance. However, it should be kept in mind that we are missing data on two countries in all the stock market regressions. Russia, a country with very weak investor protection, had a large fall in its stock market (of the order of Indonesia) but joined the IFC index only in November 1997, so we do not have the requisite stock market information. 26 The Czech Republic has struggled to establish investor protection, but by 1997 was beginning to institute a reasonable set of safeguards (Johnson and Shleifer 1999). Its stock market (measured by the IFC's Investable Index) fell 22 percent in 1997 and only 7.3 percent in 1998. If Russia and the Czech Republic were included, our results would be stronger and the dependence on Indonesia reduced.

Our results show that ex post returns including the crash of 1997-98 are lower where institutions are weaker and where there is, as a result, more risk. This is not inconsistent with the argument that ex ante expected returns in the stock market should be higher where governance is weaker. We do not have evidence about expected returns before the crisis in these markets.

\section{Conclusion}

A simple model shows managerial agency problems can make countries with weak legal systems vulnerable to the effects of a sudden loss of investor confidence. Countries with weakly enforceable minority shareholder rights are particularly vulnerable. If such a country experiences even a small loss of confidence, outside investors reassess the likely amount of

\footnotetext{
${ }^{26}$ Russia's IFC Investable Index fell 84.2 percent in 1998 (IFC 1999). The change in this index for 1997 is not available.
} 
expropriation by managers and adjust the amount of capital they are willing to provide. The result can be a fall in asset values and a collapse of the exchange rate.

In cross-country regressions, corporate governance variables explain more of the variation in exchange rates and stock market performance during the Asian crisis than do macroeconomic variables. This result is not sensitive to changing the sample period, altering the precise definition of variables, or dropping outliers.

This does not mean that macroeconomic explanations are not important in the Asian crisis. While there is no agreement among economists about the relative importance of the current account, reserves, foreign debt, monetary policy and fiscal policy for emerging markets in 1997-98, there is widespread agreement that macro policies were important in particular instances. However, as our results show, these variables did not have simple or direct effects in determining the extent of crisis across emerging market countries in 1997-98.

Our evidence suggests that corporate governance in general, and the de facto protection of minority shareholder rights in particular, mattered a great deal for the extent of exchange rate depreciation and stock market decline in 1997-98. Although our results do not indicate which countries are vulnerable to a loss of confidence, they do suggest that the extent of exchange rate and stock market collapse in response to a loss of confidence is affected by investor protection. Corporate governance can be of first order importance for determining the extent of macroeconomic problems in crisis situations. 
References

Biers, Dan editor 1998. Crash of '97: How the Financial Crisis is Reshaping Asia. Review Publishing Company Limited (Far Eastern Economic Review), Hong Kong.

Brunswick Warburg 1999. “Russia Value Monitor.” Moscow, June.

Caballero, Ricardo and Arvind Krishnamurthy 1998. "Emerging Markets Crises: An Asset Markets Perspective.” Mimeo, November 21, MIT.

Cornelius, Peter 1999. “The value-at-risk of countries.” Mimeo, Harvard Institute for International Development.

Corsetti, Giancarlo, Paolo Pesenti, and Nouriel Roubini 1998. "What caused the Asian currency and financial crisis?" Mimeo, Revised March.

Flemings Research 1998, Global Emerging Markets, June.

Folkerts-Landau, David, and Peter Garber, 1998, "Capital Flows from Emerging Markets in a Closing Environment" (London: Deutsche Bank Research, Global Emerging Markets, October). 
Friedman, Eric and Simon Johnson 1999, "Propping and Looting in a Weak Legal

Environment," Manuscript, MIT, October.

Goldman Sachs 1997. Emerging Markets Biweekly, December 10.

Goldman Sachs 1998. The Weekly Analyst, January 27.

Goldman Sachs 1999. Emerging Markets Economics Quarterly. July 1999.

Greenspan, Alan 1998. Testimony of Chairman Alan Greenspan Before the Committee on Banking and Financial Services, U.S. House of Representatives, January 30.

Hunter, William C., George G. Kaufman, and Thomas H. Krueger, editors 1999. The Asian Financial Crisis: Origins, Implications, and Solutions. Kluwer Academic Publishers, Boston/Dordrecht/London.

International Finance Corporation (IFC) 1998. Emerging Markets Factbook 1998. International Finance Corporation: Washington DC.

International Finance Corporation (IFC) 1999. Emerging Markets Factbook 1999. International Finance Corporation: Washington DC. 
International Monetary Fund (IMF) 1997. World Economic Outlook. Interim Assessment. International Monetary Fund, Washington DC, December.

International Organization of Securities Commissions 1998. "Causes, Effects and Regulatory Implications of Financial and Economic Turbulence in Emerging Markets: Interim Report.” Emerging Markets Committee, September.

Jensen, Michael C. and William H. Meckling 1976. “Theory of the Firm: Managerial Behavior, Agency Costs and Ownership Structure," Journal of Financial Economics, 3, 305-360.

Johnson, Simon and Andrei Shleifer 1999. "Coase v. The Coasians," manuscript, Harvard and MIT, October.

Krugman, Paul 1979. "A Model of Balance of Payments Crises," Journal of Money, Credit, and Banking, 11:311-325.

Krugman, Paul 1998. "What Happened to Asia?" Mimeo, MIT.

JP Morgan 1997. Emerging markets: economic indicators, December 5.

La Porta, Rafael, Florencio Lopez-de-Silanes, Andrei Shleifer 1999. “Corporate Ownership Around the World," Journal of Finance, 54, 471-517. 
La Porta, Rafael, Florencio Lopez-de-Silanes, Andrei Shleifer, and Robert W. Vishny 1997 , “Legal Determinants of External Finance,” Journal of Finance, pp.1131-50.

La Porta, Rafael, Florencio Lopez-de-Silanes, Andrei Shleifer, and Robert W. Vishny 1998, “Law and Finance," Journal of Political Economy, December, volume 106, Number 6, pp.11131155.

La Porta, Rafael, Florencio Lopez-de-Silanes, Andrei Shleifer, and Robert W. Vishny 1999a. “The Quality of Government," Journal of Law, Economics and Organization. 15, 222-279.

La Porta, Rafael, Florencio Lopez-de-Silanes, Andrei Shleifer, and Robert W. Vishny 1999b, “Investor Protection and Corporate Valuation.” Manuscript, Harvard and Chicago, July.

Radelet, Steven and Jeffrey D. Sachs 1998a. "The Onset of the East Asian Financial Crisis." Mimeo, February.

Radelet, Steven and Jeffrey D. Sachs 1998b. "The East Asian Financial Crisis: Diagnosis, Remedies, Prospects.” Brookings Papers on Economic Activity, 1998:1, pp.1-90.

Rajan, Raghuram G. and Luigi Zingales 1998. "Which Capitalism? Lessons from the East Asian Crisis." Journal of Applied Corporate Finance. 
Shleifer, Andrei and Robert Vishny 1997a. "A Survey of Corporate Governance." The Journal of Finance, Vol. LII, No.2, June, pp.737-783.

Shleifer, Andrei and Robert Vishny 1997b. "The Limits of Arbitrage." The Journal of Finance, Vol. LII, No.1, March, pp.35-55.

Troika Dialog 1999. "Corporate Governance in Russia.” Moscow, May.

Wade, Robert and Frank Veneroso 1998. "The Asian Crisis: The High Debt Model vs. The Wall Street-Treasury-IMF Complex.” New Left Review, March-April 1998.

World Bank 1999. Global Development Finance: Analysis and Summary Tables. Washington D.C.

Yellen, Janet 1998. "Lessons from the Asian Crisis," speech at Council on Foreign Relations, New York, April 15. 
List of abbreviations for countries used in figures

$\begin{array}{ll}\text { ARG } & \text { Argentina } \\ \text { BRA } & \text { Brazil } \\ \text { CHL } & \text { Chile } \\ \text { CHN } & \text { China } \\ \text { COL } & \text { Colombia } \\ \text { CZE } & \text { Czech } \\ \text { GRC } & \text { Greece } \\ \text { HKG } & \text { Hong Kong } \\ \text { HUN } & \text { Hungary } \\ \text { DNI } & \text { India } \\ \text { IND } & \text { Indonesia } \\ \text { ISR } & \text { Israel } \\ \text { KOR } & \text { Korea } \\ \text { MEX } & \text { Mexico } \\ \text { MYS } & \text { Malaysia } \\ \text { PHL } & \text { Philippines } \\ \text { POL } & \text { Poland } \\ \text { PRT } & \text { Portugal } \\ \text { RUS } & \text { Russia } \\ \text { SGP } & \text { Singapore } \\ \text { THA } & \text { Thailand } \\ \text { TUR } & \text { Turkey } \\ \text { TWN } & \text { Taiwan } \\ \text { VEN } & \text { Venezuela } \\ \text { ZAF } & \text { South Africa }\end{array}$


Table 1. Alleged Incidents of Stealing in the Asian Financial Crisis

\begin{tabular}{|c|c|c|c|}
\hline Company & Country & Date & Alleged Incident \\
\hline Bangkok Bank of Commerce & Thailand & 1996-97 & Bank managers moved money to offshore companies under their control. \\
\hline $\begin{array}{l}\text { United Engineers (Malaysia) } \\
\text { Bhd }\end{array}$ & Malaysia & $1997-98$ & $\begin{array}{l}\text { United Engineers bailed out its financially troubled parent, Renong Bhd, by acquiring a } 33 \% \\
\text { stake at an artificially high price. }\end{array}$ \\
\hline Malaysia Air System Bhd. & Malaysia & 1998 & The chairman used company funds to retire personal debts. \\
\hline PT Bank Bali & Indonesia & 1997-98 & Managers diverted funds in order to finance a political party. \\
\hline Sinar Mas Group & Indonesia & $1997-98$ & $\begin{array}{l}\text { Group managers transferred foreign exchange losses from a manufacturing company to a } \\
\text { group-controlled bank, effectively expropriating the bank's creditors and minority }\end{array}$ \\
\hline $\begin{array}{l}\text { Guangdong International } \\
\text { Trust \& Investment Co }\end{array}$ & Hong Kong/China & 1998-99 & $\begin{array}{l}\text { Assets that had been pledged as collateral disappeared from the company when it went } \\
\text { bankrupt. }\end{array}$ \\
\hline Siu-Fung Ceramics Co & Hong Kong/China & 1998-99 & Assets that had been pledged as collateral disappeared from the company when it went \\
\hline Tokobank & Russia & 1998-99 & $\begin{array}{l}\text { Creditors who may have been linked to bank managers took control of the bank and its } \\
\text { remaining assets following default. Foreign creditors got nothing. }\end{array}$ \\
\hline Menatep & Russia & 1998 & $\begin{array}{l}\text { Following Menatep's bankruptcy, managers transferred a large number of regional branches } \\
\text { to another bank they controlled. }\end{array}$ \\
\hline AO Yukos & Russia & 1998-99 & $\begin{array}{l}\text { Managers transferred Yukos's most valuable petroleum-producing properties to offshore } \\
\text { companies they controlled. }\end{array}$ \\
\hline Uneximbank & Russia & 1999 & $\begin{array}{l}\text { Following Uneximbank's bankruptcy, managers moved profitable credit-card processing and } \\
\text { custodial operations to another bank. }\end{array}$ \\
\hline Samsung Electronics Co. & Korea & $1997-98$ & $\begin{array}{l}\text { Managers used cash from Samsung Electronics to support other members of the Samsung } \\
\text { group (notably Samsung Motors) that were losing money. }\end{array}$ \\
\hline Hyundai & Korea & 1998-99 & $\begin{array}{l}\text { Managers of a Hyundai-controlled investment fund channelled money from retail investors } \\
\text { to loss-making firms in the Hyundai group. }\end{array}$ \\
\hline
\end{tabular}

Sources for Table 1

Wall Street Journal, May 7, 1999, p.A1; April 17, 1998, p.A12; September 21, 1999, p.A1; August 25, 1999, p.A14; April 4, 1999 , p.A1; April 8, 1999 , p.A14.

The Economist, March 27, 1999 and September 11, 1999. 
Table 2

Extent of Exchange Rate Depreciation in Emerging Markets, 1997-99

\begin{tabular}{|c|c|c|c|c|c|c|c|c|c|c|c|c|c|}
\hline \multirow[b]{4}{*}{ Argentina } & \multicolumn{6}{|c|}{\begin{tabular}{|l} 
Purchasing Power of currency \\
\end{tabular}} & \multicolumn{7}{|c|}{ Exchange Rates } \\
\hline & \begin{tabular}{|l|} 
March \\
$1998 /$ end \\
1996
\end{tabular} & $\begin{array}{l}\text { July 1998/ } \\
\text { end } 1996\end{array}$ & $\begin{array}{l}\text { Sept } \\
1998 / \text { end } \\
1996\end{array}$ & $\begin{array}{l}\text { Nov } \\
\text { 1998/end } \\
1996\end{array}$ & $\begin{array}{l}\text { Jan } \\
1999 / \text { end } \\
1996\end{array}$ & $\begin{array}{l}\text { Apr } \\
1999 / \text { end } \\
1996\end{array}$ & end-1996 & March-98 & July -98 & September-98 & Nov. 1998 & January-99 & April-99 \\
\hline & prexrate & prnomr & sept98ex & nov98ex & jan99ex & apr99ex & & & & & & & \\
\hline & 1.00 & 1.00 & 1.00 & 1.00 & 1.00 & 1.00 & 0.9998 & 1 & 1 & 1 & 1 & 1 & 1 \\
\hline Brazil & 0.92 & 0.90 & 0.88 & 0.87 & 0.66 & 0.63 & 1.04 & 1.13 & 1.16 & 1.18 & 1.19 & 1.58 & 1.66 \\
\hline Chile & 0.94 & 0.90 & 0.90 & 0.92 & 0.89 & 0.89 & 424.35 & 453 & 471 & 473 & 462 & 478 & 479 \\
\hline China & 1.00 & 1.00 & 1.00 & 1.00 & 1.00 & 1.00 & 8.30 & 8.28 & 8.28 & 8.28 & 8.28 & 8.28 & 8.28 \\
\hline Colombia & 0.74 & 0.74 & 0.67 & 0.64 & 0.63 & 0.63 & 1006.10 & 1354 & 1352 & 1498 & 1567 & 1595 & 1594 \\
\hline Czech & 0.80 & 0.83 & 0.89 & 0.93 & 0.88 & 0.78 & 27.23 & 34 & 32.9 & 30.5 & 29.4 & 31.1 & 35 \\
\hline Greece & 0.86 & 0.81 & 0.84 & 0.88 & 0.88 & 0.82 & 246.71 & 287 & 306 & 295 & 280 & 279 & 300 \\
\hline Hong Kong & 1.00 & 1.00 & 1.00 & 1.00 & 1.00 & 1.00 & 7.73 & 7.74 & 7.75 & 7.75 & 7.74 & 7.75 & 7.75 \\
\hline Hungary & 0.77 & 0.73 & 0.73 & 0.75 & 0.75 & 0.69 & 161.65 & 209 & 220 & 222 & 215 & 216 & 234 \\
\hline India & 0.91 & 0.85 & 0.84 & 0.85 & 0.84 & 0.84 & 35.83 & 39.5 & 42.2 & 42.6 & 42.3 & 42.5 & 42.8 \\
\hline Indonesia & 0.24 & 0.16 & 0.20 & 0.27 & 0.28 & 0.27 & 2362.50 & 9650 & 14500 & 11700 & 8850 & 8475 & 8625 \\
\hline Israel & 0.91 & 0.89 & 0.85 & 0.76 & 0.80 & 0.81 & 3.25 & 3.58 & 3.66 & 3.83 & 4.29 & 4.05 & 4.03 \\
\hline Korea & 0.54 & 0.62 & 0.62 & 0.64 & 0.72 & 0.70 & 845.50 & 1565 & 1371 & 1362 & 1312 & 1167 & 1214 \\
\hline Mexico & 0.92 & 0.88 & 0.76 & 0.79 & 0.77 & 0.83 & 7.87 & 8.58 & 8.93 & 10.38 & 9.94 & 10.17 & 9.51 \\
\hline Malaysia & 0.66 & 0.61 & 0.66 & 0.66 & 0.66 & 0.66 & 2.53 & 3.81 & 4.15 & 3.8 & 3.8 & 3.8 & 3.8 \\
\hline Philippines & 0.66 & 0.64 & 0.60 & 0.67 & 0.68 & 0.69 & 26.30 & 39.8 & 41.4 & 43.9 & 39.4 & 38.4 & 38.2 \\
\hline Poland & 0.82 & 0.82 & 0.79 & 0.83 & 0.81 & 0.72 & 2.86 & 3.48 & 3.49 & 3.62 & 3.43 & 3.53 & 3.98 \\
\hline Portugal & 0.83 & 0.83 & 0.88 & & 0.90 & 0.82 & 155.25 & 186 & 186 & 177 & 173.4 & 173.43 & 189.2 \\
\hline Russia & 0.93 & 0.93 & 0.33 & 0.36 & 0.24 & 0.22 & 5.59 & 6 & 6 & 17 & 15.63 & 23.2 & 25.8 \\
\hline Singapore & 0.86 & 0.83 & 0.81 & 0.87 & 0.84 & 0.83 & 1.41 & 1.64 & 1.69 & 1.74 & 1.62 & 1.68 & 1.69 \\
\hline Thailand & 0.58 & 0.61 & 0.63 & 0.70 & 0.70 & 0.68 & 25.64 & 44.4 & 42.1 & 41 & 36.6 & 36.5 & 37.6 \\
\hline Turkey & 0.47 & 0.41 & 0.39 & 0.38 & 0.33 & 0.29 & 109095.00 & 232155 & 267530 & 276400 & 290120 & 329000 & 379280 \\
\hline Taiwa & 0.86 & 0.80 & 0.79 & 0.85 & 0.85 & 0.84 & 27.50 & 32 & 34.4 & 34.6 & 32.5 & 32.3 & 32.9 \\
\hline Venezuela & 0.92 & 0.86 & 0.81 & 0.84 & 0.83 & 0.81 & 476.26 & 519 & 555 & 587 & 567 & 571 & 589 \\
\hline South Africa & 0.95 & 0.78 & 0.75 & 0.84 & 0.78 & 0.77 & 4.68 & 4.93 & 6.01 & 6.24 & 5.57 & 6 & 6.08 \\
\hline
\end{tabular}

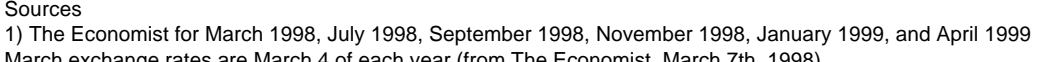

July exchange rates are July 1 (from The Economist, July 4th, 1998)

September exchange rates are September 9th (from The Economist, September 12th, 1998)

November exchange rates are November 4th (from The Economist, November 7th, 1998; this issue did not report a rate for Portugal);

the November 1998 exchange rate for Portugal is from the International Finance Corporation's Emerging Markets Database (1999).

January 1999 exchange rates are January 20th (from The Economist, January 23rd, 1999); Portugal is from the Wall Street Journal, January 28

April 1999 exchange rates are April 21st (from The Economist, April 24th, 1999); Portugal is from the Financial Times April 23

2) IFC 1998, p.32 for end of 1996

(The IFC does not report an exchange rate for Hong Kong and Singapore; these are from The Economist, January 2nd, 1999)

The first six columns show the change in purchasing power of the currency, taking the end of 1996 as equal to 1 .

Change in purchasing power is calculated as (exchange rate at the end of 1996)/(exchange rate in 1998 or 1999)

Exchanges for 1098 and 1090 ar in 8 he

All exchange rates are

The sample is the 25 "emerging markets," as viewed by international investors.

These are relatively large developing countries open to capital flows.

We use the set of countries classified as emerging markets by The Economist (although Portugal was dropped from this group in 1998), JP Morgan, and Goldman Sachs. 
Table 3

Data Used in Regressions

\section{Macroeconomic Variables}

Government

budget balance Broad Money

as a Percent of Growth, \% per

GDP, 1996 annum, 1996

jpgov gpmoney

$\begin{array}{lrr}\text { Argentina } & -2.0 & 19.8 \\ \text { Brazil } & -3.9 & 28.9 \\ \text { Chile } & 2.2 & 23.6\end{array}$

Chile

China

Colombia

Czech

Greece

Hong Kong

Hungary

India

Indonesia

Israel

Korea

Mexico

Malaysia

Philippines

Poland

Portugal

Russia

Singapore

Thailand

Turkey

Taiwan

South Africa

Source

and see below

13.6

and see below
Total Reserves, Import Coverage, Total Foreign

billions of US months of

as a Percent of dollars at the end imports, at the

GDP, 1996

of 1996

jpreser

end of 1996

jpcover

-1.3
-3.3

$-3.3$

0.9
-5.4

$-5.4$

$-8.0$

-3.7
1.9

1.9
-3.2

$-1.1$

$-3.4$

$-7.0$

$-4.7$

$-0.6$

$-6.3$

$-4.5$

-1.0
-1.4

2.1

15.2

$-4.3$

$-2.4$

4.0

$-1.6$

Goldman Sachs

Morgan

and see below

$\begin{array}{cc}18.1 & 5.8 \\ 60.1 & 5.7 \\ 14.8 & 8.7 \\ 107.0 & 8.8 \\ 9.6 & 6.3 \\ 12.4 & 3.4 \\ 17.5 & 5.8 \\ 63.8 & 3.9 \\ 9.8 & 3.5 \\ 20.2 & 5.2 \\ 18.3 & 4.6 \\ 11.4 & 3.1 \\ 33.2 & 1.5 \\ 19.4 & 2.1 \\ 27.0 & 2.6 \\ 10.0 & 2.1 \\ 17.8 & 5.3 \\ 21.9 & 5.7 \\ 11.3 & 3.1 \\ 76.8 & 6.0 \\ 37.7 & 4.4 \\ 16.5 & 3.5 \\ 88.0 & 6.9 \\ 11.8 & 8.8 \\ 0.9 & 1.5 \\ & \\ \text { Morgan } & \text { JP Morgan } \\ \text { and see below }\end{array}$

end of 199

jpextern

24,449

150,54

26,898

20,412

55,336

491,100
27,646

95,797

121,374

47,600

106,922

169,675

38,553

56,616

41,628

65,010

123,117

288,500

98,368

79,747

42,797

32,927

JP Morgan

and see below

and see below

and see below

a Percent of

as a Percent of

Short-term Debt

jpamort

Percent of

GDP Ratio, end

$\begin{array}{ll}105,388 & 311 \\ 194,046 & 296 \\ 24,449 & 114\end{array}$

and see be

Countries Missing

Sample Size

22

25

25

25

25

21 
Table 3 (continued)

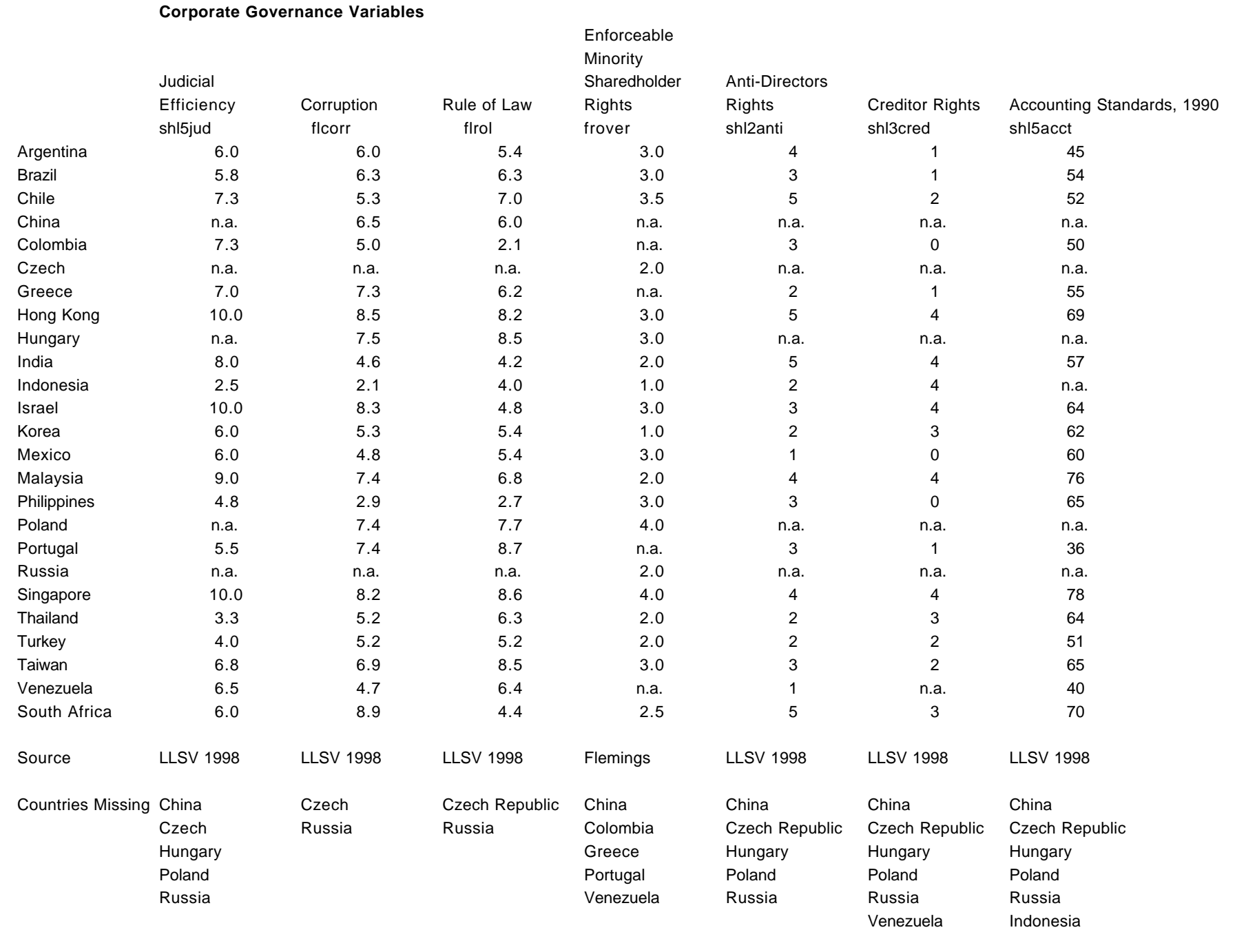

20

23

23

20

20

19

19

LLSV 1998 is La Porta, Lopez-de-Silanes, Shleifer, and Vishny 1998. 
Table 3 (continued)

\begin{tabular}{|c|c|c|c|}
\hline & $\begin{array}{l}\text { IFC Investable } \\
\text { Index in at lowest } \\
\text { point in } 1998 \\
\text { (with end of } \\
\text { 1996=100) }\end{array}$ & $\begin{array}{l}\text { IFC Investable } \\
\text { Index at end of } \\
1998 \text { (with end of } \\
1996=100 \text { ) }\end{array}$ & $\begin{array}{l}\text { Month in which } \\
\text { IFC Investable } \\
\text { Index reached } \\
\text { lowest point in } \\
1998\end{array}$ \\
\hline Argentina & 68.9 & 83.9 & August \\
\hline Brazil & 69.4 & 69.4 & September \\
\hline Chile & 62.4 & 72.8 & August \\
\hline China & 29.0 & 35.5 & August \\
\hline Colombia & 51.6 & 69.4 & October \\
\hline Czech & 59.4 & 72.3 & August \\
\hline India & 75.0 & 81.5 & November \\
\hline Greece & 124.9 & 255.5 & January \\
\hline Hong Kong & 41.1 & 47.8 & September \\
\hline Hungary & 103.9 & 142.6 & September \\
\hline Indonesia & 8.5 & 19.0 & September \\
\hline Israel & 94.7 & 102.2 & October \\
\hline Korea & 30.6 & 68.7 & September \\
\hline Mexico & 73.7 & 90.5 & August \\
\hline Malaysia & 12.8 & 26.3 & August \\
\hline Philippines & 22.7 & 41.9 & August \\
\hline Poland & 63.3 & 71.5 & August \\
\hline Portugal & 158.8 & 199.8 & September \\
\hline Russia & n.a. & n.a. & September \\
\hline Singapore & 40.8 & 61.2 & September \\
\hline Thailand & 14.3 & 28.5 & August \\
\hline Turkey & 90.7 & 98.4 & October \\
\hline Taiwan & 66.3 & 75.6 & August \\
\hline Venezuela & 37.5 & 62.3 & August \\
\hline South Africa & 49.7 & 60.0 & August \\
\hline Source & IFC 1999 & IFC 1999 & IFC 1999 \\
\hline Countries Missing & Russia & Russia & \\
\hline Sample Size & 24 & 24 & \\
\hline
\end{tabular}

IFC 1999 is International Finance Corporation (1999) 


\section{Table 3 (continued)}

Additional numbers to fill gaps (at recommendation of referee) are from:

Fiscal deficit in Israel, Portugal and Venezuela (from World Bank 1999)

Broad money growth in Greece, Israel and Portugal (from World Bank 1999)

Current account in Israel and Portugal (from World Bank 1999)

Total reserves in Israel and Portgual (from World Bank 1999)

Import coverage in Israel, Portugal, and Singapore (from World Bank 1999); data for Hong Kong calculated from Political Risk Services (1999).

Total foreign debt for Hong Kong, Israel and Singapore (from Goldman Sachs 1999); data for Portugal from Political Risk Services (1999)

Foreign debt as a percent of exports for Hong Kong and Singapore (from Goldman Sachs 1999); data for Portugal and Israel from Political Risk Services (1999).

Interest payments as a percent of exports for Israel from Political Risk Services 1999

External Debt-GDP ratio for Hong Kong and Singapore (from Goldman Sachs 1999); data for Israel and Portugal from Political Risk Services (1999)

Note that the information on debt/exports and interest payments/exports and debt/GDP for Hong Kong and Singapore is for early 1999

Variable definitions not given in column headings

Judicial Efficiency Table 1 in LLSV (1998) describes this variable as follows.

Assessment of the "efficiency and integrity of the legal environment as it affects business, particularly foreign firms" produced by the country-risk rating agency Business International Corporation.

It "may be taken to represent investors' assessments of conditions in the country in question." Average between 1980 and 1983. Scale from 0 to 10, with lower scores [meaning] lower efficiency levels.

Corruption

The data for China, Hungary, Poland are not in LLSV (1998) but were provided by Lopez-de-Silanes (1998). Table 1 in LLSV (1998) describes this variable as follows.

ICR's assessment of the corruption in government. Lower scores indicate that "high government officials are likely to demand special payments" and "illegal payments are generally expected throughout lower levels of government

in the form of "bribes connected with import and export licenses, exchange controls, tax assessment, policy protection, or loans."

Average of the months of April and October of the monthly index between 1982 and 1995. Scale from 0 to 10 , with lower scores for higher levels of corruption. (We [LLSV] changed the scale from its original range going from 0 to 6. .)

Rule of law The data for China, Hungary, Poland were again provided by Lopez-de-Silanes (1998). Table 1 in LLSV (1998) describes this variable as follows.

Assessment of the law and order tradition in the country produced by the country-risk rating agency International Country Risk (ICR).

Average of the months of April and October of the monthly index between 1982 and 1995.

Scale from 0 to 10, with lower scores for less tradition for law and order. (We [LLSV] changed the scale from its original range going from 0 to 6 )

Anti-director rights Table 1 in LLSV (1998) describes this variable as follows.

An index aggregating the shareholder rights which we labeled as "anti-director rights." The index is formed by adding 1 when: (1) the country allows shareholders to mail their proxy vote to the firm;

(2) shareholders are not required to deposit their shares prior to the General Shareholders' Meeting; (3) cumulative voting or proportional representation of minorities in the board of directors is allowed;

(4) an oppressed minorities mechanism is in place; (5) the minimum percentage of share capital that entitles a shareholder to call for an Extraordinary Shareholders' Meeting is less than or equal to 10 percent (the sample median);

or (6) shareholders have preemptive rights that can only be waived by a shareholders' vote. The index ranges from 0 to 6

Creditor rights Table 1 in LLSV (1998) describes this variable as follows.

An index aggregating different creditor rights. The index is formed by adding 1 when (1) the country imposes restrictions, such as creditors' consent or minimum dividends to file for reorganization:

(2) secured creditors are able to gain possession of their security once the reorganization petition has been approved (no automatic stay);

(3) secured creditors are ranked first in the distribution of the proceeds that result from the disposition of the assets of a bankrupt firm;

and (4) the debtor does not retain the administration of its property pending the resolution of the reorganization. The index ranges from zero to four.

Accounting standards Table 1 in LLSV (1998) describes this variable as follows.

Index created by examining and rating companies' 1990 annual reports on their inclusion or omission of 90 items.

These items fall into seven categories (general information, income statements, balance sheets, funds flow statement, accounting standards, stock data, and special items.) A minimum of three companies in each country were studied.

The companies represent a cross section of various industry groups; industrial companies represented 70 percent, and financial companies represented the remaining 30 percent. 
Table 4

Macroeconomic Variables

\begin{tabular}{|c|c|c|c|c|c|c|c|c|c|c|}
\hline \multirow[b]{2}{*}{ East Asia dummy } & \multicolumn{10}{|c|}{ Dependent variable: exchange rate purchasing power in January 1999 (end of Dec.1996=1) } \\
\hline & & $\begin{array}{l}-0.02 \\
(0.10)\end{array}$ & & $\begin{array}{l}-0.07 \\
(0.08)\end{array}$ & & $\begin{array}{l}-0.01 \\
(0.1)\end{array}$ & & $\begin{aligned}-0.13 \\
(0.1)\end{aligned}$ & & $\begin{aligned}-0.03 \\
(0.1)\end{aligned}$ \\
\hline $\begin{array}{l}\text { Fiscal and Monetary Policy } \\
\text { Government Budget Balance } \\
\text { jpgov }\end{array}$ & $\begin{array}{c}0.02 \\
(0.01)\end{array}$ & $\begin{array}{l}0.02 \\
(0.01)\end{array}$ & & & & & & & & \\
\hline $\begin{array}{l}\text { Broad Money Growth } \\
\text { gpmoney }\end{array}$ & & & $\begin{array}{l}-0.007^{*} \\
(0.004)\end{array}$ & $\begin{array}{l}-0.008^{*} \\
(0.004)\end{array}$ & & & & & & \\
\hline $\begin{array}{l}\text { Current Account and Reserv } \\
\text { Current Account } \\
\text { jpcurr }\end{array}$ & & & & & $\begin{array}{l}0.006 \\
(0.008)\end{array}$ & $\begin{array}{l}0.006 \\
(0.008)\end{array}$ & & & & \\
\hline $\begin{array}{l}\text { Total Reserves } \\
\text { jpreser }\end{array}$ & & & & & & & $\begin{array}{l}0.0024 \\
(0.002)\end{array}$ & $\begin{array}{l}0.004^{* *} \\
(0.002)\end{array}$ & & \\
\hline $\begin{array}{l}\text { Import Coverage } \\
\text { jpcover }\end{array}$ & & & & & & & & & $\begin{array}{l}0.04^{*} \\
(0.02)\end{array}$ & $\begin{array}{l}0.04^{*} \\
(0.02)\end{array}$ \\
\hline R-squared & 0.09 & 0.1 & 0.12 & 0.15 & 0.02 & 0.03 & 0.11 & 0.17 & 0.16 & 0.16 \\
\hline Adjusted R-squared & 0.05 & 0.02 & 0.08 & 0.07 & -0.02 & -0.07 & 0.07 & 0.1 & 0.12 & 0.08 \\
\hline Observations & 25 & 25 & 24 & 24 & 25 & 25 & 25 & 25 & 25 & 25 \\
\hline $\begin{array}{l}\text { Coefficient and standard error } \\
\text { if drop transition countries }\end{array}$ & $\begin{array}{l}0.007 \\
(0.010)\end{array}$ & $\begin{array}{c}0.009 \\
(0.010)\end{array}$ & $\begin{array}{l}-0.004 \\
(0.004)\end{array}$ & $\begin{array}{l}-0.005 \\
(0.004)\end{array}$ & $\begin{array}{c}0.01 \\
(0.007)\end{array}$ & $\begin{array}{c}0.01 \\
(0.008)\end{array}$ & $\begin{array}{c}0.002 \\
(0.002)\end{array}$ & $\begin{array}{l}0.004^{* *} \\
(0.002)\end{array}$ & $\begin{array}{l}0.03^{*} \\
(0.017)\end{array}$ & $\begin{array}{c}0.03^{*} \\
(0.018)\end{array}$ \\
\hline Countries not in regression & & & Turkey & Turkey & & & & & & \\
\hline
\end{tabular}

${ }^{* *}$ : significant at $5 \%$ level

$*$ : significant at $10 \%$ level

Standard errors are in brackets 


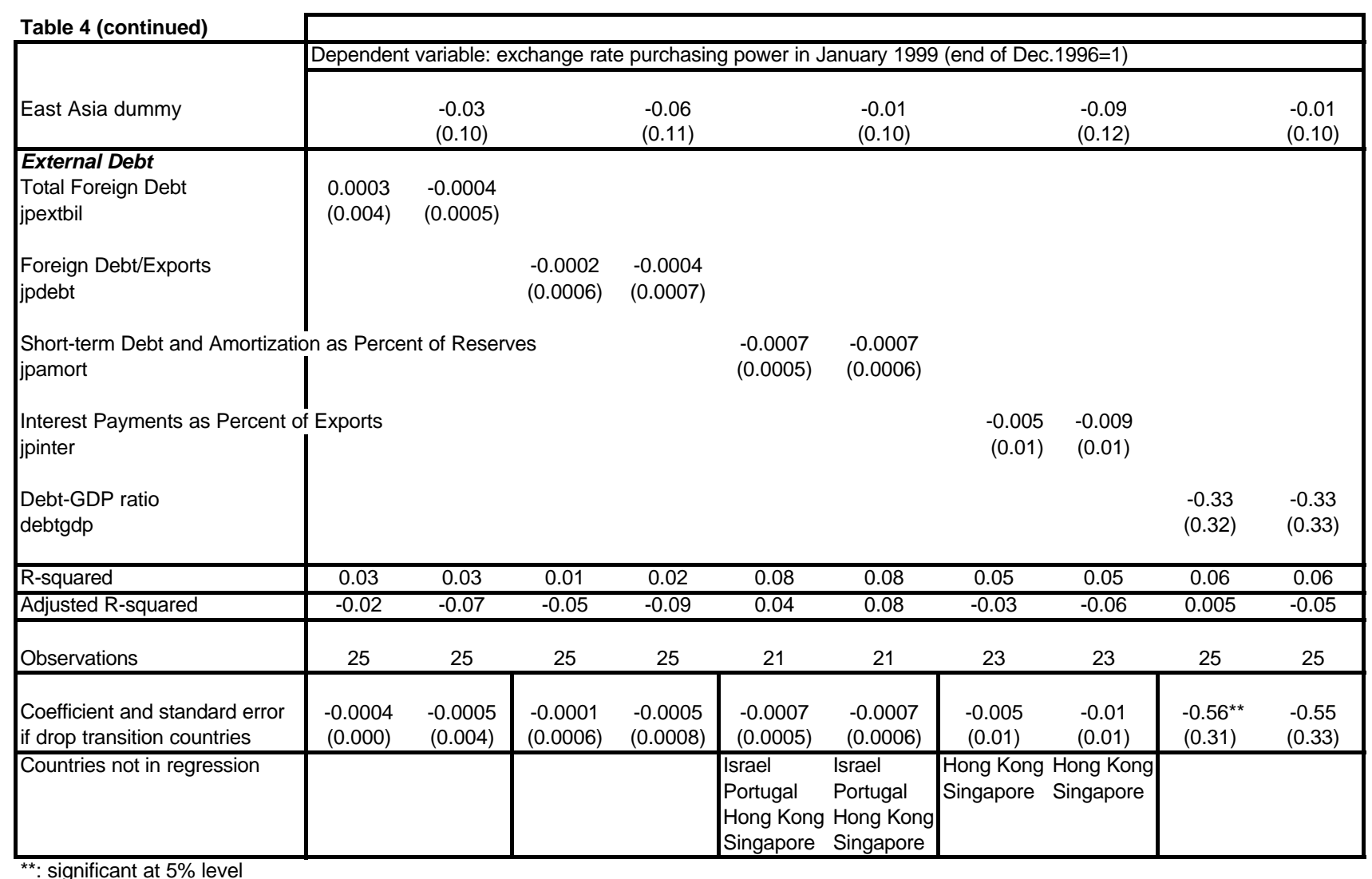

*: significant at $10 \%$ level

Standard errors are in brackets 


\section{Table 4 (continued)}

Notes

All results are for OLS regressions with exchange purchasing power as the dependent variable.

Exchange rate purchasing power is lower in January 1999 relative to the end of 1996 if there has been more depreciation.

Therefore a positive coefficient on a variable means it is associated with less depreciation.

All regressions use the full sample for which data is available, but

Turkey is dropped from the money growth regression.

\section{Definition of variables used in regressions}

Government budget balance is the central government's budget deficit (if negative) or surplus (if positive) as a percent of GDP in 1996.

Broad money growth is the growth of a broad money aggregate in 1996.

Current account is the country's current account deficit (if negative) or surplus (if positive) as a percent of GDP in 1996.

Total reserves are central bank reserves in billions of dollars at the end of 1996.

Import coverage is the ratio of imports to reserves, measured in months of imports, in 1996.

Total foreign debt is the stock of private and public debt in foreign currency outstanding at the end of 1996, in US dollars.

Short-term debt and amortization as a percent of reserves measures payments on foreign debt in 1996.

Interest payments as a percent of exports were in 1996.

Debt-GDP ratio is the ratio of foreign debt outstanding at the end of 1996 to GDP in 1996.

The transition countries are China, Czech Republic, Hungary, Poland, and Russia.

The East Asia dummy is equal to one for China, Hong Kong, Indonesia, Korea, Malaysia, Philippines, Singapore, Thailand, and Taiwan.

The dependent variable is the purchasing power of the currency vis-à-vis the US dollar in January 1999, taking the end of 1996 as equal to 100 .

The values used are in Table 1. 
Table 5

Enforceability of Contracts

\begin{tabular}{|c|c|c|c|c|c|c|c|c|c|c|c|c|}
\hline \multirow{2}{*}{\begin{tabular}{|l|} 
\\
East Asia Dummy \\
\end{tabular}} & \multicolumn{12}{|c|}{ Dependent variable: exchange rate purchasing power in January 1999 (end-Dec.1996=100) } \\
\hline & & $\begin{array}{l}-0.06 \\
(0.07)\end{array}$ & $\begin{array}{c}-0.1 \\
(0.09)\end{array}$ & & $\begin{array}{l}-0.005 \\
(0.07)\end{array}$ & $\begin{array}{l}-0.09 \\
(0.09)\end{array}$ & & $\begin{array}{l}-0.05 \\
(0.07)\end{array}$ & $\begin{array}{l}-0.13 \\
(0.09)\end{array}$ & & $\begin{array}{c}0.04 \\
(0.09)\end{array}$ & $\begin{array}{l}0.01 \\
0.12\end{array}$ \\
\hline \multicolumn{13}{|c|}{ Enforceability of Contracts } \\
\hline $\begin{array}{l}\text { Judicial Efficiency } \\
\text { shl5jud }\end{array}$ & $\begin{array}{l}0.05^{\star *} \\
(0.02)\end{array}$ & $\begin{array}{l}0.05^{* \star} \\
(0.02)\end{array}$ & $\begin{array}{l}0.05^{* *} \\
(0.02)\end{array}$ & & & & & & & & & \\
\hline \begin{tabular}{|l} 
Corruption \\
flcorr
\end{tabular} & & & & $\begin{array}{l}0.05^{* *} \\
(0.02)\end{array}$ & $\begin{array}{l}0.05^{\star \star} \\
(0.02)\end{array}$ & $\begin{array}{l}0.04^{*} \\
(0.02)\end{array}$ & & & & & & \\
\hline $\begin{array}{l}\text { Rule of Law } \\
\text { flrol }\end{array}$ & & & & & & & $\begin{array}{l}0.04^{\star \star} \\
(0.02)\end{array}$ & $\begin{array}{l}0.04^{\star \star} \\
(0.02)\end{array}$ & $\begin{array}{c}0.03 \\
(0.02)\end{array}$ & & & \\
\hline $\begin{array}{l}\text { Enforceable Shareholc } \\
\text { Corporate Governance } \\
\text { frover }\end{array}$ & Jer Rights & & & & & & & & & $\begin{array}{l}0.14^{\star \star} \\
(0.05) \\
\end{array}$ & $\begin{array}{l}0.14^{\star *} \\
(0.05) \\
\end{array}$ & $\begin{array}{l}0.13^{* *} \\
(0.06) \\
\end{array}$ \\
\hline \begin{tabular}{|l} 
Macroeconomic Contr \\
Reserves \\
jpreser
\end{tabular} & ol Variable & & $\begin{array}{c}0.002 \\
(0.002)\end{array}$ & & & $\begin{array}{c}0.002 \\
(0.002)\end{array}$ & & & $\begin{array}{c}0.003 \\
(0.002)\end{array}$ & & & $\begin{array}{c}0.001 \\
(0.002)\end{array}$ \\
\hline R-squared & 0.34 & 0.37 & 0.39 & 0.28 & 0.28 & 0.36 & 0.19 & 0.2 & 0.27 & 0.3 & 0.31 & 0.31 \\
\hline Adjusted R-Squared & 0.31 & 0.29 & 0.28 & 0.2 & 0.21 & 0.25 & 0.15 & 0.12 & 0.14 & 0.26 & 0.22 & 0.18 \\
\hline Observations & 20 & 20 & 20 & 23 & 23 & 23 & 23 & 23 & 23 & 20 & 20 & 20 \\
\hline Missing Countries & \begin{tabular}{|l} 
China \\
Hungary \\
Poland \\
Russia \\
Czech R.
\end{tabular} & \begin{tabular}{|l} 
China \\
Hungary \\
Poland \\
Russia \\
Czech R.
\end{tabular} & $\begin{array}{l}\text { China } \\
\text { Hungary } \\
\text { Poland } \\
\text { Russia } \\
\text { Czech R. }\end{array}$ & $\begin{array}{l}\text { Russia } \\
\text { Czech R. }\end{array}$ & $\begin{array}{l}\text { Russia } \\
\text { Czech R. }\end{array}$ & $\begin{array}{l}\text { Russia } \\
\text { Czech R. }\end{array}$ & $\begin{array}{l}\text { Russia } \\
\text { Czech R. }\end{array}$ & $\begin{array}{l}\text { Russia } \\
\text { Czech R. }\end{array}$ & $\begin{array}{l}\text { Russia } \\
\text { Czech R. }\end{array}$ & \begin{tabular}{|l} 
China \\
Colombia \\
Greece \\
Portugal \\
Venezuela
\end{tabular} & $\begin{array}{l}\text { China } \\
\text { Colombia } \\
\text { Greece } \\
\text { Portugal } \\
\text { Venezuela }\end{array}$ & $\begin{array}{l}\text { China } \\
\text { Colombia } \\
\text { Greece } \\
\text { Portugal } \\
\text { Venezuela }\end{array}$ \\
\hline
\end{tabular}

**: significant at $5 \%$ level

Standard errors are in brackets 
Table 5 (continued)

Shareholder Protection, Creditor Rights, and Accounting Standards

\begin{tabular}{|c|c|c|c|c|c|c|c|c|c|c|c|c|c|c|c|c|c|c|}
\hline & Dependent & variable: $\mathrm{e}$ & xcha & purchasing & power in $\mathrm{J}$ & anuary 1 & (end of $\mathrm{D \epsilon}$ & mber 1 & $\overline{b=1)}$ & & & & & & & & & \\
\hline East Asia dummy & & $\begin{array}{l}-0.06 \\
(0.08)\end{array}$ & $\begin{array}{l}-0.13 \\
(0.10)\end{array}$ & & $\begin{array}{l}-0.1 \\
(0.10)\end{array}$ & $\begin{array}{l}-0.11 \\
(0.10)\end{array}$ & & $\begin{array}{l}-0.06 \\
(0.08)\end{array}$ & $\begin{array}{l}-0.11 \\
(0.10)\end{array}$ & & $\begin{array}{c}-0.1 \\
(0.07)\end{array}$ & $\begin{array}{l}-0.11 \\
(0.10)\end{array}$ & & $\begin{array}{l}-0.06 \\
(0.10)\end{array}$ & $\begin{array}{l}-0.12 \\
(0.12)\end{array}$ & & $\begin{array}{c}0.03 \\
(0.10)\end{array}$ & $\begin{array}{c}-0.02 \\
(0.12)\end{array}$ \\
\hline Shareholder Protection & & & & & & & & & & & & & & & & & & \\
\hline $\begin{array}{l}\text { Antidirector Rights } \\
\text { shl2anti }\end{array}$ & $\begin{array}{l}0.06^{*} \\
(0.03)\end{array}$ & $\begin{array}{l}0.06^{*} \\
(0.03)\end{array}$ & $\begin{array}{l}0.05^{*} \\
(0.03)\end{array}$ & & & & & & & & & & & & & & & \\
\hline Antidirector Rights x Judi & icial Efficienc & & & $\begin{array}{l}0.007^{* *} \\
(0.003)\end{array}$ & $\begin{array}{l}0.007^{\star *} \\
(0.003)\end{array}$ & $\begin{array}{l}0.007^{\star \star} \\
(0.003)\end{array}$ & & & & & & & & & & & & \\
\hline $\begin{array}{l}\text { Antidirector Rights } \times \text { Corr } \\
\text { corranti }\end{array}$ & ruption & & & & & & $\begin{array}{l}0.008^{\star *} \\
(0.003)\end{array}$ & $\begin{array}{l}0.008^{\star \star} \\
(0.003)\end{array}$ & $\begin{array}{l}0.007^{*} \\
(0.003)\end{array}$ & & & & & & & & & \\
\hline $\begin{array}{l}\text { Antidirector Rights } \times \text { Rule } \\
\text { rolanti }\end{array}$ & of Law & & & & & & & & & $\begin{array}{l}0.01^{\star \star} \\
(0.003)\end{array}$ & $\begin{array}{l}0.01^{* *} \\
(0.003)\end{array}$ & $\begin{array}{l}0.01^{\star \star} \\
(0.004)\end{array}$ & & & & & & \\
\hline $\begin{array}{l}\text { Creditor Rights } \\
\text { Creditor Rights } \\
\text { shl3cred }\end{array}$ & & & & & & & & & & & & & $\begin{array}{l}-0.007 \\
(0.03)\end{array}$ & $\begin{array}{l}0.007 \\
(0.03)\end{array}$ & $\begin{array}{l}-0.003 \\
(0.04)\end{array}$ & & & \\
\hline $\begin{array}{l}\text { Accounting Standards } \\
\text { Accounting Standards } \\
\text { shl5acct }\end{array}$ & & & & & & & & & & & & & & & & $\begin{array}{l}-0.0008 \\
(0.003)\end{array}$ & $\begin{array}{l}-0.002 \\
(0.01)\end{array}$ & $\begin{array}{l}-0.005 \\
(0.01)\end{array}$ \\
\hline Macroeconomic Contro & I Variable & & & & & & & & & & & & & & & & & \\
\hline $\begin{array}{l}\text { Reserves } \\
\text { jpreser }\end{array}$ & & & $\begin{array}{c}0.003 \\
(0.002)\end{array}$ & & & $\begin{array}{c}0.002 \\
(0.002)\end{array}$ & & & $\begin{array}{c}0.002 \\
(0.002)\end{array}$ & & & $\begin{array}{c}0.001 \\
(0.002)\end{array}$ & & & $\begin{array}{c}0.003 \\
(0.002)\end{array}$ & & & $\begin{array}{c}0.002 \\
(0.002)\end{array}$ \\
\hline R-Squared & 0.17 & 0.2 & 0.29 & 0.26 & 0.3 & 0.35 & 0.25 & 0.28 & 0.33 & 0.29 & 0.37 & 0.38 & 0.003 & 0.02 & 0.16 & 0.004 & 0.009 & 0.06 \\
\hline \begin{tabular}{|l|} 
Adjusted R-Squared \\
\end{tabular} & 0.13 & 0.11 & 0.16 & 0.22 & 0.22 & 0.23 & 0.21 & 0.2 & 0.21 & 0.25 & 0.3 & 0.26 & -0.06 & -0.1 & -0.02 & -0.05 & -0.12 & -0.13 \\
\hline Observations & 20 & 20 & 20 & 20 & 20 & 20 & 20 & 20 & 20 & 20 & 20 & 20 & 19 & 19 & 19 & 19 & 19 & 19 \\
\hline \begin{tabular}{|l} 
Missing Countries \\
\end{tabular} & \begin{tabular}{|l} 
China \\
Hungary \\
Poland \\
Russia \\
Czech R.
\end{tabular} & $\begin{array}{l}\text { China } \\
\text { Hungary } \\
\text { Poland } \\
\text { Russia } \\
\text { Czech R. }\end{array}$ & $\begin{array}{l}\text { China } \\
\text { Hungary } \\
\text { Poland } \\
\text { Russia } \\
\text { Czech R. }\end{array}$ & \begin{tabular}{|l} 
China \\
Hungary \\
Poland \\
Russia \\
Czech R.
\end{tabular} & $\begin{array}{l}\text { China } \\
\text { Hungary } \\
\text { Poland } \\
\text { Russia } \\
\text { Czech R. }\end{array}$ & $\begin{array}{l}\text { China } \\
\text { Hungary } \\
\text { Poland } \\
\text { Russia } \\
\text { Czech R. }\end{array}$ & \begin{tabular}{|l} 
China \\
Hungary \\
Poland \\
Russia \\
Czech R.
\end{tabular} & $\begin{array}{l}\text { China } \\
\text { Hungary } \\
\text { Poland } \\
\text { Russia } \\
\text { Czech R. }\end{array}$ & $\begin{array}{l}\text { China } \\
\text { Hungary } \\
\text { Poland } \\
\text { Russia } \\
\text { Czech R. }\end{array}$ & \begin{tabular}{|l} 
China \\
Hungary \\
Poland \\
Russia \\
Czech R.
\end{tabular} & $\begin{array}{l}\text { China } \\
\text { Hungary } \\
\text { Poland } \\
\text { Russia } \\
\text { Czech R. }\end{array}$ & $\begin{array}{l}\text { China } \\
\text { Hungary } \\
\text { Poland } \\
\text { Russia } \\
\text { Czech R. }\end{array}$ & \begin{tabular}{|l} 
China \\
Hungary \\
Poland \\
Russia \\
Czech R. \\
Venezuela
\end{tabular} & $\begin{array}{l}\text { China } \\
\text { Hungary } \\
\text { Poland } \\
\text { Russia } \\
\text { Czech R. } \\
\text { Venezuela }\end{array}$ & \begin{tabular}{l|} 
China \\
Hungary \\
Poland \\
Russia \\
Czech R. \\
Venezuela
\end{tabular} & \begin{tabular}{|l} 
China \\
Hungary \\
Poland \\
Russia \\
Czech R. \\
Indonesia
\end{tabular} & $\begin{array}{l}\text { China } \\
\text { Hungary } \\
\text { Poland } \\
\text { Russia } \\
\text { Czech R. } \\
\text { Indonesia }\end{array}$ & $\begin{array}{l}\text { China } \\
\text { Hungary } \\
\text { Poland } \\
\text { Russia } \\
\text { Czech R. } \\
\text { Indonesia }\end{array}$ \\
\hline
\end{tabular}

**: significant at $5 \%$ level

Standard errors are in brackets 


\section{Table 5 (continued)}

\section{Definition of variables used in regression}

Judicial Efficiency is an index from 0 to 10 , for the period 1980-83, with a higher score meaning a more efficient legal system from the perspective of foreign business people.

Corruption is an index from $\mathrm{O}$ to 10 , for the period 1982-95, with a higher score meaning that there is less bribery among government officials.

Rule of law is an index from 0 to 10, for the period 1982-95, with a higher score meaning a stronger tradition of law and order.

Corporate Governance is an index from 1 to 5 , for early 1998 , with a higher score indicating better treatment for minority shareholders.

Antidirector Rights is an index from 0 to 6 , for 1996-97, with a higher score indicating better protection for minority shareholders.

Creditor Rights is an index from 0 to 4 , for 1996-97, with a higher score indicating better protection for creditors.

Accounting standards is an index from 0 to 90 , for 1990 with a higher score indicating more disclosure in company annual reports.

Total reserves are central bank reserves in billions of dollars at the end of 1996 .

Four measures are constructed through multiplying indices together.

Antidirector Rights $x$ Judicial Efficiency is the product of Antidirector Rights and Judicial Efficiency

Antidirector Rights $x$ Corruption is the product of Antidirector Rights and Corruption.

Antidirector Rights $\times$ Rl

The East Asia dummy is equal to one for China, Hong Kong, Indonesia, Korea, Malaysia, Philippines, Singapore, Thailand, and Taiwan.

The dependent variable is the purchasing power of the currency vis-à-vis the US dollar in January 1999, taking the end of 1996 as equal to 100 The values used are in Table 1 . 
Table 6

Change in Stock Market Value and Macroeconomic Policies.

\begin{tabular}{|c|c|c|c|c|c|c|c|}
\hline \multirow[b]{2}{*}{ East Asia dummy } & \multicolumn{5}{|c|}{ Stock Market Value at lowest point in 1998 with end $1996=100$} & \multicolumn{2}{|l|}{ ifc96981 } \\
\hline & $\begin{array}{l}-49.5^{\star \star} \\
(12.0)\end{array}$ & & $\begin{array}{l}-61.2^{\star \star} \\
(14.1)\end{array}$ & & $\begin{array}{l}-53.3^{* *} \\
(12.6)\end{array}$ & & $\begin{array}{l}-41.7^{\star \star} \\
(11.7)\end{array}$ \\
\hline $\begin{array}{l}\text { Current Account } \\
\text { jpcurr }\end{array}$ & $\begin{array}{l}-0.7 \\
(1.4)\end{array}$ & & & & & & \\
\hline $\begin{array}{l}\text { Total Reserves } \\
\text { jpreser }\end{array}$ & & $\begin{array}{l}-0.3 \\
(0.3)\end{array}$ & $\begin{array}{c}0.35 \\
(0.25)\end{array}$ & & & & \\
\hline $\begin{array}{l}\text { Debt-GDP Ratio } \\
\text { debtgdp }\end{array}$ & & & & $\begin{array}{c}-7.2 \\
(11.8)\end{array}$ & $\begin{array}{c}8 \\
(9.6)\end{array}$ & & \\
\hline $\begin{array}{l}\text { Government Budget Balance } \\
\text { jpgov }\end{array}$ & & & & & & $\begin{array}{l}-5.0^{* *} \\
(1.9)\end{array}$ & $\begin{array}{l}-3.0^{* *} \\
(1.6)\end{array}$ \\
\hline Observations & 25 & 25 & 25 & 25 & 25 & 25 & 25 \\
\hline$\overline{R-S q u a r e d}$ & 0.01 & 0.05 & 0.5 & 0.02 & 0.47 & 0.25 & 0.53 \\
\hline Adjusted R-Squared & -0.03 & 0.01 & 0.45 & -0.03 & 0.42 & 0.21 & 0.49 \\
\hline
\end{tabular}

**: significant at $10 \%$ level

*: significant at $5 \%$ level

Standard errors are in parentheses

\section{Notes to Table 6}

Government budget balance is the central government's budget deficit (if negative) or surplus (if positive) as a percent of GDP in 1996

Current account is the country's current account deficit (if negative) or surplus (if positive) as a percent of GDP in 1996.

Total reserves are central bank reserves in billions of dollars at the end of 1996.

Debt-GDP ratio is the ratio of foreign debt outstanding at the end of 1996 to GDP in 1996.

The East Asia dummy is equal to one for China, Hong Kong, Indonesia, Korea, Malaysia, Philippines, Singapore, Thailand, and Taiwan.

The dependent variable is the value of the IFC Investable Index, measured in US dollars, at its lowest point in 1998, taking the value of this index at the end of 1996 to equal 100. The values used are in Table 2 . 
Table 7

Change in Stock Market Value and Legal Institutions

\begin{tabular}{|c|c|c|c|c|c|c|c|c|c|c|c|c|c|c|c|c|}
\hline \multirow[b]{2}{*}{ East Asia dummy } & \multicolumn{6}{|c|}{ Stock Market Value at lowest in 1998 with end $1996=100$} & \multicolumn{6}{|l|}{ ifc9698I } & & & \multirow[b]{2}{*}{$\begin{array}{l}-41.3^{\star *} \\
(8.4)\end{array}$} & \multirow[b]{2}{*}{$\begin{array}{l}-53.4^{\star \star} \\
(10.1)\end{array}$} \\
\hline & & & $\begin{array}{l}-50.1^{\star \star} \\
(13.6)\end{array}$ & $\begin{array}{l}-63.6^{\star \star} \\
(15.9)\end{array}$ & & & $\begin{array}{l}-48.2^{* \star} \\
(11.3)\end{array}$ & $\begin{array}{l}-55.0^{\star \star} \\
(15.0)\end{array}$ & & & $\begin{array}{l}-53.8^{\star \star} \\
(10.5)\end{array}$ & $\begin{array}{l}-56.0^{\star \star} \\
(13.5)\end{array}$ & & & & \\
\hline $\begin{array}{l}\text { Efficiency of Judiciary } \\
\text { shl5jud }\end{array}$ & $\begin{array}{c}2 \\
(4.2)\end{array}$ & $\begin{array}{l}2.8 \\
(4.5)\end{array}$ & $\begin{array}{c}1.8 \\
(3.2)\end{array}$ & $\begin{array}{c}0.003 \\
(3.3)\end{array}$ & & & & & & & & & & & & \\
\hline $\begin{array}{l}\text { Corruption } \\
\text { flcorr }\end{array}$ & & & & & $\begin{array}{l}7.6^{*} \\
(4.3)\end{array}$ & $\begin{array}{l}9.4^{* *} \\
(4.2)\end{array}$ & $\begin{array}{l}5.9^{*} \\
(3.2)\end{array}$ & $\begin{array}{c}4.9 \\
(3.5)\end{array}$ & & & & & & & & \\
\hline $\begin{array}{l}\text { Rule of Law } \\
\text { flrol }\end{array}$ & & & & & & & & & $\begin{array}{c}6 \\
(4.2)\end{array}$ & $\begin{array}{c}10.0^{\star *} \\
(4.3)\end{array}$ & $\begin{array}{l}7.5^{*} \\
(2.8)\end{array}$ & $\begin{array}{l}7.1^{\star *} \\
(3.3)\end{array}$ & & & & \\
\hline $\begin{array}{l}\text { Corporate Governance } \\
\text { frover }\end{array}$ & & & & & & & & & & & & & $\begin{array}{l}12.9^{*} \\
(7.50) \\
\end{array}$ & $\begin{array}{l}15.0^{*} \\
(7.60) \\
\end{array}$ & $\begin{array}{c}6.3 \\
(5.00) \\
\end{array}$ & $\begin{array}{r}1.7 \\
(5.3) \\
\end{array}$ \\
\hline $\begin{array}{l}\text { Macroeconomic Control Variable } \\
\text { Reserves } \\
\text { jpreser }\end{array}$ & & $\begin{array}{l}-0.3 \\
(0.4)\end{array}$ & & $\begin{array}{c}0.5 \\
(0.3)\end{array}$ & & $\begin{array}{l}-0.5^{*} \\
(0.3)\end{array}$ & & $\begin{array}{l}-0.2 \\
(0.3)\end{array}$ & & $\begin{array}{l}-0.6 \\
(0.3)\end{array}$ & & $\begin{array}{l}0.07 \\
(0.3)\end{array}$ & & $\begin{array}{l}-0.30 \\
(0.3)\end{array}$ & & $\begin{array}{l}0.4^{*} \\
(0.2)\end{array}$ \\
\hline Obs & 20 & 20 & 20 & 20 & 23 & 23 & 23 & 23 & 23 & 23 & 23 & 23 & 19 & 19 & 19 & 19 \\
\hline R-Squared & 0.01 & 0.04 & 0.45 & 0.52 & 0.13 & 0.24 & 0.54 & 0.56 & 0.09 & 0.26 & 0.61 & 0.61 & 0.15 & 0.22 & 0.66 & 0.73 \\
\hline Adjusted R-Squared & -0.04 & -0.08 & 0.39 & 0.43 & 0.09 & 0.17 & 0.5 & 0.49 & 0.05 & 0.18 & 0.57 & 0.55 & 0.1 & 0.12 & 0.62 & 0.67 \\
\hline Countries missing & $\begin{array}{l}\text { China } \\
\text { Czech } \\
\text { Hungary } \\
\text { Poland } \\
\text { Russia }\end{array}$ & $\begin{array}{l}\text { China } \\
\text { Czech } \\
\text { Hungary } \\
\text { Poland } \\
\text { Russia }\end{array}$ & $\begin{array}{l}\text { China } \\
\text { Czech } \\
\text { Hungary } \\
\text { Poland } \\
\text { Russia }\end{array}$ & $\begin{array}{l}\text { China } \\
\text { Czech } \\
\text { Hungary } \\
\text { Poland } \\
\text { Russia }\end{array}$ & $\begin{array}{l}\text { Czech } \\
\text { Russia }\end{array}$ & $\begin{array}{l}\text { Czech } \\
\text { Russia }\end{array}$ & $\begin{array}{l}\text { Czech } \\
\text { Russia }\end{array}$ & $\begin{array}{l}\text { Czech } \\
\text { Russia }\end{array}$ & \begin{tabular}{|l} 
Czech \\
Russia
\end{tabular} & $\begin{array}{l}\text { Czech } \\
\text { Russia }\end{array}$ & $\begin{array}{l}\text { Czech } \\
\text { Russia }\end{array}$ & $\begin{array}{l}\text { Czech } \\
\text { Russia }\end{array}$ & $\begin{array}{l}\text { China } \\
\text { Colombia } \\
\text { Greece } \\
\text { Portugal } \\
\text { Venezuela } \\
\text { Russia }\end{array}$ & $\begin{array}{l}\text { China } \\
\text { Colombia } \\
\text { Greece } \\
\text { Portugal } \\
\text { Venezuela } \\
\text { Russia }\end{array}$ & $\begin{array}{l}\text { China } \\
\text { Colombia } \\
\text { Greece } \\
\text { Portugal } \\
\text { Venezuela } \\
\text { Russia }\end{array}$ & $\begin{array}{l}\text { China } \\
\text { Colombia } \\
\text { Greece } \\
\text { Portugal } \\
\text { Venezuela } \\
\text { Russia }\end{array}$ \\
\hline
\end{tabular}

**: significant at $5 \%$ level

$*$ : significant at $10 \%$ level

Standard errors are in parentheses

\section{Notes to Table 7}

Judicial Efficiency is an index from 0 to 10, for the period 1980-83, with a higher score meaning a more efficient legal system

from the perspective of foreign business people.

Corruption is an index from $\mathrm{O}$ to 10 , for the period 1982-95, with a higher score meaning that there is less bribery among government officials.

Rule of law is an index from 0 to 10, for the period 1982-95, with a higher score meaning a stronger tradition of law and order.

Corporate Governance is an index from 1 to 5 , for early 1998, with a higher score indicating better treatment for minority shareholders.

The East Asia dummy is equal to one for China, Hong Kong, Indonesia, Korea, Malaysia, Philippines, Singapore, Thailand, and Taiwan.

The dependent variable is the value of the IFC Investable Index, measured in US dollars, at its lowest point in 1998, taking the value of this index at the end of 1996 to equal 100 . The values used are in Table 2 . 